\title{
Navigating the London-French Transnational Space: The Losses and Gains of Language as Embodied and Embedded Symbolic Capital
}

\author{
Saskia Huc-Hepher (D)
}

check for

updates

Citation: Huc-Hepher, Saskia. 2021. Navigating the London-French Transnational Space: The Losses and Gains of Language as Embodied and Embedded Symbolic Capital. Languages 6: 57. https://doi.org/ 10.3390/languages6010057

Received: 4 February 2021

Accepted: 16 March 2021

Published: 22 March 2021

Publisher's Note: MDPI stays neutral with regard to jurisdictional claims in published maps and institutional affiliations.

Copyright: (C) 2021 by the author. Licensee MDPI, Basel, Switzerland. This article is an open access article distributed under the terms and conditions of the Creative Commons Attribution (CC BY) license (https:/ / creativecommons.org/licenses/by/ $4.0 /)$.
School of Humanities, University of Westminster, London W1B 2HW, UK; S.V.Huc-Hepher@westminster.ac.uk

\begin{abstract}
In this article, an interdisciplinary lens is applied to French migrants' reflections on their everyday language practices, investigating how embodied and embedded language, such as accent and London-French translanguaging, serve as both in-group and out-group symbolic markers in different transnational spaces. Key sociological concepts developed by Pierre Bourdieu are deployed, including field, habitus, hysteresis and symbolic capital, to assess the varying symbolic conversion rates of the migrants' languaging practices across transnational spaces. A mixed-methodological and analytical approach is taken, combining narratives from ethnographic interviews and autobiography. Based on the data gathered, the article posits that the French accent is an embodied symbolic marker, experienced as an internalised dialectic: a barrier to inclusion/belonging in London and an escape from the symbolic weight of the originary accent in France. Subsequently, it argues that the migrants' translanguaging functions as a spontaneous insider vernacular conducive to community identity construction in the postmigration space, but (mis)interpreted as an exclusionary articulation of symbolic distinction in the premigration context. Finally, the article asks whether participants' linguistic repertoires, self-identifications and spatialities go beyond the notion of the 'cleft habitus', or even hybridity, to a post-structural, translanguaging third space that transcends borders.
\end{abstract}

Keywords: symbolic capital; linguistic habitus; cleft habitus; hysteresis; translanguaging; London French; in-group vernacular; accent; othering; third space

\section{Introduction}

This article stems from several years of research on French residents in London. Being a comparatively privileged migrant group, it is a population that has received little scholarly attention, and the few existing studies tend to concentrate on an unrepresentative, highly skilled sub-group (Block 2006; Favell 2008; Mulholland and Ryan 2011, 2014a, 2014b, 2016; Ryan and Mulholland 2013, 2014) or on the diaspora outside London (Brahic and Lallement 2018). Deborah Reed-Danahay's recent anthropological work on a more diverse segment of the community holds much promise (Reed-Danahay 2020a, 2020b), but the full fruits of her research have yet to be disseminated, with the coronavirus pandemic causing further delay (Reed-Danahay 2020a). Historically, the French have been considered an unproblematic diasporic minority (Kelly 2013) and their positive contributions to the British capital, be they in the form of gastronomy, education, fashion or financial services (Office for National Statistics 2017), have only compounded this invisibilisation. Nevertheless, given the size and sociolinguistic complexities of the London-French diaspora, they are a population worthy of academic scrutiny. Consular records indicate that there were 146,213 French residents registered in the UK in 2018 and 147,548 in 2019 (Ministère de 1'Europe et des Affaires étrangères 2019). At $0.91 \%$, this growth is relatively minor compared to previous years, as demonstrated by the 2011 ONS census figures-up from 38,000 residents born in France in 2001 to 129,804 a decade later-and constitutes less than half the 300-400,000 estimate often cited by the French Embassy (Mulholland and Ryan 2016). However, being in the hundreds of thousands by all measures and, until 2020 (Ministère de 1'Europe et des 
Affaires étrangères), continuing to grow in spite of the Home Office's 'hostile environment' and the UK's 2016 referendum-based decision to leave the EU, the London-French are a diasporic case whose numeric weight alone validates further enquiry.

The specific angle of the enquiry presented here is the migrants' experience of language as both an embodied disposition, with varying rates of symbolic capital within and across the transnational field(s), and as a stimulus for (dis)embedding and in-group (un)belonging depending on the translocal context. In particular, I investigate the ambivalent implications of the French accent as an embodied marker of externalised positive and negative symbolic significance, connoting, for example, culinary expertise and/or hypersexuality, national and/or regional background, and experienced as an internalised impediment and/or a liberating force. Subsequently, I explore the migrants' situated translanguaging practices (Blackledge and Creese 2010; Lewis et al. 2012; Li and Zhu 2013; Li 2011, 2016, 2018; MacSwan 2017) and the dichotomous function thereof according to the translocal setting. I demonstrate how, on the one hand, this non-standard LondonFrench vernacular serves to strengthen in-group belonging and embedding within the postmigration space (Giles and Johnson 1987). On the other, it disembeds and uproots participants from the premigration 'home', where their pre-reflexive use of Anglicisms for efficiency or economy, are misconceived as affected devices of social distinction (Koven 2013). This conversion of symbolic capital gain to symbolic capital loss translates into othering and exclusion from previously strong affective bonds. Finally, I ask whether the translanguaging practices of the London-French diaspora transcend the notion of the 'cleft habitus' (Bourdieu 2004; Thatcher and Halvorsrud 2016), or even that of hybridity (Li 2018) or the hybrid habitus (Decoteau 2013; Pulley and Whaley 2020), by gesturing towards a post-structural conception of language as a borderless phenomenon (Otheguy et al. 2015) that disrupts national, lexical and disciplinary divides (Cacciatore and Pepe 2019; Seloni 2019). Or is it an ideal borne of a transnational epistemology at odds with the ontological vécu of the migrants themselves?

Before progressing to the body of this article, it is important to underline that my disciplinary background in French Studies has informed the methodological and conceptual framework underpinning the analysis. Rather than a sociopragmatic (Holmes 2018) examination of French migrants' language use in practice, I examine their reflective and affective accounts of embodied and embedded translanguaging, doing so through a narrative-focused interdisciplinary lens that combines ethnographic and literary approaches. The synergies between ethnography and modern languages have been established elsewhere (Wells et al. 2019), with 'openness and curiosity' and 'language as embodied social practice' being defined as 'impulses' common to both disciplines (op. cit., p.1). However, I would argue that ethnography and modern languages also have a mutual concern for the written word. Positioned at the interface of (social) science and literature (Debaene 2010), ethnography is an intrinsically descriptive form of study, whose emphasis on writing is integral to its identity ('graphy'). Similarly, I apprehend transcribed participant narratives and autobiographical testimony in much the same way I would a literary work. As Kate Pahl posits, by combining disciplines, we are 'making our fields come alive' and, as such, 'we push the field into a more contingent, alive space, which is layered through our encounters' (Pahl 2019, p. 145). The terminology, analytical style and theoretical framework adopted in this paper might, therefore, differ from the other articles in the Special Issue, but the data collection methods and research questions remain fundamentally germane and arguably contribute to the scholarly 'liveliness' of the Issue as a whole. Below, I provide a more detailed account of the paper's methodological and conceptual underpinning.

\section{A Bourdieusian Methodological and Conceptual Framework}

Classified as a sociologist rather than an anthropologist, Pierre Bourdieu's repeated emphasis on the epistemological value of practice to understand wider societal structures nevertheless has much in keeping with contemporary ethnographic research methodologies. His insistence on observing the minutiae of individuals' everyday practices and 
his own sustained immersion in the cultures of his object of study, be they the village cultures of the Béarn (Bourdieu [1962] 2002), the domestic cultures of the Kabyle household (Bourdieu [1972] 2000) or the working cultures of education (Bourdieu and Passeron 1964, 1970; Bourdieu 1984, 1989), were methods that served as a precursor to ethnography as it is understood today. In addition, Bourdieu's endorsement of theory emerging from practice (Bourdieu 1994), of acknowledging the implications of the researcher's positioning (Bourdieu and Wacquant 1992) and of drawing on a range of sources-including statistics, photographs, interviews, non-academic literature and participant observation (Bourdieu 1994) - resonate with the holistic methodologies deployed by contemporary ethnographers.

Following a Bourdieusian model, therefore, my own research methods seek to explore the everyday practices of French migrants living in London, as articulated through a variety of methods, including interviews and focus groups, on-land and on-line participant observation, multimodal digital representations and London-French autobiography (Cordier 2005; de Roquemaurel 2014; Senni 2007). For the purposes of this article, however, I draw specifically on data I collected in twenty semi-structured, in-depth interviews with a diverse sample of London-French migrants, together with the personal insights provided by Josselin de Roquemaurel in his autobiographical work La Reine, la City et les Grenouilles: Chroniques d'un Français de Londres (de Roquemaurel 2014). Whilst ostensibly incongruous, this union of spoken data collected in the field with published first-person writing is in fact an innovative marriage that challenges disciplinary boundaries, makes for a rounded research object and lends itself to a close reading. The written testimony serves to triangulate the interview data and mitigates the risk of 'methodological monotheism' ['monothéisme méthodologique'] (Bourdieu and Wacquant 1992, p. 198). Moreover, de Roquemaurel's contemplations on his relationship with language in the diasporic context have much in common with the first-person accounts gathered in my interviews and observed in the field. Despite the different audiences and functions, both are narrative forms containing intimate reflections on individual language praxis and its indexical meanings relating to identity and belonging (De Fina 2006).

Specifically, my interviewees ranged in age from twenty-four to eighty and in length of London residency from three to forty-seven years. Their professions were equally diverse, spanning catering, logistics and singing, to law, teaching, journalism and medicine. Geographically, the picture was again a heterogeneous one, with participants' premigration 'homes' including small towns and villages in rural northeast and west France, together with major cities such as Bordeaux, Lyon, Paris and Marseille, and even French-speaking Canada and Reunion Island. Similarly, their postmigration abodes stretched from Bromley in south London to Archway in the north, from Chiswick in the west to Bethnal Green in the east. Significantly, however, only one of my respondents (Sarah) came close to the City-banker profile to which de Roquemaurel corresponds and which accounts for a considerable proportion of the London-French population, particularly that associated with the established South Kensington community (Faucher et al. 2015) ${ }^{1}$. Indeed, de Roquemaurel is one of only three migrants in my study who self-identify as members of the French community in London and the only migrant who admits, in the opening pages of his book, to being a living stereotype, aptly fitting the highly skilled, City-working, southwest London-dwelling profile of the twenty-first-century French Londoner. But his account is also evocative of the challenges and unease of being a Frenchman in a foreign city, at times the victim of subtle forms of symbolic violence and having the sensation of never fully belonging to the culture of adoption. The insights de Roquemaurel's autobiographical narrative provide into his experience of languaging in the transnational space are therefore a necessary addition to my interview data.

Regarding the recruitment of my participants, I deployed a three-pronged model combining targeted selection, self-selection and snowballing in an effort to obtain a sample that

1 By way of example, in 1945-1946, tradesmen, hoteliers and restaurateurs constituted the largest segment of French Lycée (South Kensington) parents, with bankers being the second smallest group. But in 2014, bankers had risen to third position, representing 600 children, against only four in the 1940s (Faucher et al. 2015). 
would represent the diversity of this heterogeneous population. Having been immersed in the London-French community for almost two decades, three interviewees were known to me and invited to discuss their experiences with me informally over coffee. Three others had initially completed a pilot survey I conducted at the Grenadine supplementary school in Blackheath and indicated on the questionnaire that they were willing to be interviewed. Subsequently, a short article about my project was published in the monthly community magazine Ici Londres, following which three additional interviewees were recruited. And three more volunteered during a public talk I gave at the French Institute. Five others were invited to participate when I encountered them by chance in the field and the remaining three came forward through an organic process of snowballing. A six-part series of broadcasts I did for French Radio London generated new participation interest, but by that point, my sample contained a satisfactory cross-section of the community and data saturation had been reached; the interviews were consequently limited to twenty. Most were conducted in public spaces, such as cafés, but for convenience (and quiet), some took place in participants' workplaces, on University premises or in interviewees' homes (for example, the eighty-year-old respondent for whom travel was difficult). For those no longer based in London and two other London-based participants who preferred the relative anonymity of the telephone, the interviews were conducted by landline call. The average length of the conversations was 1.5 to $2 \mathrm{~h}$, all of which, bar one, were carried out in French (respondents were asked if they preferred the interview to be conducted in French or English, according to the language they felt most comfortable speaking). With their permission, I audio-recorded all the interviews (providing approximately $35 \mathrm{~h}$ of recorded data) and transcribed them verbatim, totalling around 160,000 words (or 500 pages). I subsequently colour-coded the data based on the recurrent themes identified and translated only the most salient examples into English. Dragon Naturally Speaking® voice-recognition and NVivo@ qualitative-data-analysis software was used to support transcription and coding respectively. It is important to add that all my interviews were conducted in a pre-EUReferendum period, specifically from May 2011 to July 2012. Participants' sentiments and attitudes are therefore likely to have evolved since, but this snapshot of their contemplations on language use during that pre-"Brexit" era is no less edifying for it. Indeed, their remarks are arguably more objective, and hence reliable, being free from the toxic forces dominating the political and social structures of the diasporic space from 2015 onwards ${ }^{2}$.

Returning to the theory underpinning this article, my emphasis on London-French migrants' linguistic practices, and what these complex repertoires tell us about their transnational identity, emplacement and belonging (Blommaert et al. 2005), led me to the internalexternal dynamic of 'habitus linguistiques' (Bourdieu [1982] 2001, p. 60) and a multidimensional conceptual framework inspired by Bourdieusian thinking. Bourdieu's celebrated formula, '[(habitus) (capital) $]+$ field = practice' (Burke et al. 2016, p. 3) usefully schematises the interrelational concepts I deploy in this article. It clearly demonstrates how an individual's practices are the corollary of both the habitus, that is, a reproductive set of characteristics shaped by one's filial and educational upbringing, and the cultural capital acquired from that formative setting, whether incorporated (internalised), objectivated (externalised materially) or institutionalised (officially acknowledged) (Bourdieu 1979). Crucially, the formula illustrates how these two factors, habitus and capital, combine and interact with the external field to govern one's practices. When applied to the case of French migrants in London, we note how the core habitus feature of language finds itself destabilised through mobility to a new external field, notably London. In this unfamiliar setting not only do the migrants have to learn how to negotiate the different structuring forces at play, adjusting their habitus where possible to do so, but they need to realign their apparatus of perception according to 'local economies of value' (Wallace 2016, p. 51). For, as Bourdieu asserts regarding language and specific styles of discourse, each individual

2 See the Epilogue to French London: A blended ethnography of a migrant city (Huc-Hepher 2021, in press) and Reed-Danahay (2020a, 2020b) for post-EU-Referendum findings-though not geared towards language in particular. 
'is a perceived-being who exists only in relation to perceiving subjects endowed with diacritical dispositions which allow distinctions to be made between different ways of saying and between distinctive arts of speaking' (Bourdieu [1982] 2001, p. 61; original emphasis) ${ }^{3}$. Engrained and embodied linguistic habitus dispositions which are challenging to transform, such as one's accent (Bourdieu 2005), can therefore trigger 'internalised struggles' (Thatcher and Halvorsrud 2016, p. 88). Likewise, the externalised symbolic affordances of such linguistic dispositions undergo a process of conversion when transposed to the postmigration setting, with other people's perceptions largely determining the migrants' internalised experience of their accent. This can result in losses or gains in symbolic capital within the transnational post- and premigration social space(s).

According to Bourdieu, linguistic value is established not by competence alone, but by the recognition speakers receive from others, which constitutes its symbolic worth within the 'économie des échanges linguistiques' (Bourdieu [1982] 2001, p. 57). It is precisely this concept, 'this sort of magic efficacy' (op. cit., p. 107) by which speech is apprehended 'symbolically through the veil of rhetorical illusion' (Bourdieu and Passeron 1964, p. 75) and, as such, alchemically transformed from linguistic matter into rateable semiotic resource, that I examine below 4 . Additional Bourdieusian concepts to be applied to the analysis are the potential for a 'cleft habitus' (Bourdieu 2004; Thatcher and Halvorsrud 2016) or hybrid habitus (Decoteau 2013; Pulley and Whaley 2020), resulting from the force of the transnational field on participants' linguistic habitus, notably, the disconcerting hysteresis sensation triggered by the mismatch between the external field and their embodied dispositions. While Bourdieu defines the cleft habitus as a painful splitting of the self, caused by a tension between the primary and secondary habitus, from twofold socialisation or from "'double structural constraints"' (Bourdieu 1997, p. 190), it is relevant that Nicola Ingram and Jessie Ingram and Abrahams (2016) do not conceive of a cleft habitus as necessarily alienating and negative. Rather, they emphasise 'the need to move beyond the idea of divisiveness in relation to the internalisation of contradictory structures in order to give way to thinking of the potentially creative aspects of the process of bringing sets of structures together that don't belong', suggesting 'belonging in neither and both places at once' and as such being 'displaced to a third space' (Ingram and Abrahams 2016, p. 152).

Focusing on participants' reflections on their language use, therefore, I will explore how migration may or may not prompt the development of a constructive third space (Bhabha 1994). I will ask whether their fluid translanguaging sees the emergence of a linguistically hybrid ideal that transcends the dichotomies of bilingualism and codeswitching (Blom and Gumperz 1972; Auer 1984), as Li Wei posits (Li 2018), or whether the transnational geographically, culturally and linguistically in-between space results in a form of hysteresis whereby 'the environment with which they are actually confronted is too far removed from that to which they are objectively adjusted' (Bourdieu [1972] 2000, p. 260$)^{5}$.

\section{Results and Discussion}

\subsection{The Embedded and Embodied Symbolic Status of the French Language and Accent}

The French language occupies an important place in French culture, be it on field or habitus levels. Illustrating its centrality in the originary and diasporic fields are such organisations as the Académie Française, the Organisation Internationale de la Francophonie (OIF), France's worldwide network of lycées, Alliances Françaises and Instituts Français, all designed to protect and promote French and increase its reach beyond national borders. These formal external structures demonstrate the importance attributed to everyday French language use and could help to explain why my participants' relationship to language,

3 Original: 'est un être-perçu qui n'existe qu'en relation avec des sujets percevants, dotés de ces dispositions diacritiques qui permettent de faire des distinctions entre des manières de dire différentes, des arts de parler distinctifs' (translated by Huc-Hepher, as is the case with all subsequent translations of quotations from primary and secondary sources in French).

4 Original: 'cette sorte d'efficace magique' and 'symboliquement ... à travers le voile de l'illusion rhétorique'.

5 Original: 'l'environnement auquel elles s'affrontent réellement est trop éloigné de celui auquel elles sont objectivement ajustées'. 
accent and linguistic transformation are so intensely experienced. The contextual field forces in the premigration space not only shaped their primary linguistic habitus, but influence the way in which they undergo an emerging secondary linguistic habitus in the postmigration field 6 . That is, 'correct', standardised expression in French is so engrained and safeguarded (Doran 2004; Harrison and Joubert 2019) - to the extent of being legislated for in France (see the 1994 Toubon Act)—-that the migrants' linguistic transformation and translanguaging practices can be experienced as a deficit rather than an asset. In this opening analytical subsection, however, the focus of the discussion is on the symbolic status of French in the London space, particularly in its incorporated form as accent.

On the level of habitus, the French tongue is considered essential to my research participants' identity and carries complex symbolic meanings. As Sarah, a thirty-sevenyear-old head of investment risk in a City firm, originally from Lyon and now living in Greenwich, sums up: 'my French identity, it's my language, it's the link to food, and nothing much else' ${ }^{7}$. Not only does this assertion echo Di Salvo's (2017) conclusions on the symbolic role of (the Italian) language as a marker of national identity and heritage in a diasporic context (Toronto), but the association between language and food is also telling. It points to the importance of both in French culture (UNESCO 2010) and, more importantly, to the organic physicality of language as an embodied articulation of Frenchness and its essential place in everyday life. Taking a step beyond the internalised experience of language, its symbolic value is evoked by Robert, a 40-year-old lecturer in French, and Bruno, a 37-yearold head chef, who have lived in London for 17 and 19 years respectively. They consider the French accent to have positive affordances within the situated context of London. Through a mirroring of 'host' perceptions, they perceive their indelible French accent to be representative of 'the French touch ... because people recognise us immediately owing to our accent, but I also think ... it has a positive side in the cookery world', explains Bruno $^{8}$. For him, the material legacy of the French chefs and French culinary craft capital that has infiltrated the postmigration space through generations of migration to London has bequeathed a symbolic inheritance of benefit to his professional activity and perceived status. This may be why, as de Roquemaurel posits in his autobiographical work, '[s]ome people go as far as to exaggerate their French accent proudly flaunting its Frenchness, like a nationalistic statement' (de Roquemaurel 2014, p. 82) ${ }^{9}$. However, what Robert describes as a 'bel accent', and others purportedly hyerbolise as an embodied affirmation of their cultural heritage, is experienced by others in less favourable terms.

Financial and IT consultant Brice, a thirty-three-year-old East London resident of fourteen years, originally from the medieval town of Carcassonne in southwest France, draws attention to the symbolic ambiguity of the French accent, claiming it to harbour positive and negative affordances simultaneously. In keeping with the 'split figures' referred to by Stuart Hall (1997, p. 229), Brice claims the French accent to be an indexical identity marker of both 'le charmeur ou romantique' and an individual who is 'arrogant and doesn't wash'10. This inherent ambivalence thus embodies mainstream British media tropes, whereby the French are systematically othered through their mythologised representations (Barthes 1957) as

6 The confines of this article prevent an in-depth discussion of this point, but it is an important underlying factor that came through in participants' testimonies and, as such, should be borne in mind when considering their narratives. For example, Sarah commented on how she does not 'like the way young French people speak on public transport ... in France as a whole, our French is becoming poorer, our vocabulary is reducing. Everyone uses young people's expressions, although we're not young anymore ... I'm not a good example because my French is not improving' ['je n'aime pas la façon dont les jeunes Français parlent le français dans les transports en commun ... dans l'ensemble en France, notre français s'appauvrit, notre vocabulaire diminue. On utilise tous des expressions des jeunes, alors qu'on n'est plus jeunes ... Moi, je suis pas un bon exemple parce que mon français ne s'améliore pas']. The individuated incorporation of prescriptivist premigration field structures and its postmigration continuance thus consitutes fertile ground for future research.

7 Original: 'mon identité française, c'est ma langue, c'est le lien à la nourriture, et puis pas grand-chose d'autre'. NB: to protect participant anonymity, all interviewee names are pseudonyms.

8 Original: 'le French Touch ... parce qu'on nous reconnaît de suite par rapport à notre accent, mais je pense aussi que ... ça a un côté positif... en cuisine'.

9 Original: ‘[c]ertains vont même jusqu'à exagérer leur accent français ... arborant fièrement la francité de leur accent, comme une revendication nationaliste'.

10 Original: 'arrogant, qui se lave pas'. 
hypersexualised and attractive and concurrently unclean, malodourous and repulsive (Huc-Hepher 2019). As Hall explains, "'difference" is ambivalent. It can be both positive and negative. It is both necessary for the production of meaning, the formation of language and culture, for social identities and a subjective sense of the self as a sexed subject-and at the same time, it is threatening, a site of danger, or negative feelings, of splitting, hostility and aggression towards the "Other"' (Hall 1997, p. 238). On a personal level, Brice is sufficiently proficient in French and English to be able to manipulate the French accent to his own whimsical ends: 'I play around with the cliché' ${ }^{11}$. He nevertheless acknowledges that its ultimate symbolic weight is determined by the listener, for whom it becomes 'a new inward sign' (Kress 2010, p. 32): 'people throw in what they want, which often means stereotypes ${ }^{\prime 2}$. This realisation, then, confirms the transubstantiation process underscored by Bourdieu and the symbolic potency of language, placing some in positions of domination, in this case the host population, and others in subordination, here the French migrants. The ambivalent role of language in the postmigration space therefore plays out as an insidious form of xenophobic symbolic violence (Bourdieu [1982] 2001, pp. 210-11; Blommaert et al. 2005).

Suzanne, a Dijon-born octogenarian who has lived in London since the 1960s, explains how the generalisations and stereotyping associated with the French accent are quickly converted into prejudice and conducive to symbolic harm: 'I really hate generalising, I hate it, because when people do it to me: "you're French, so...", "the French, so...", it hurts ${ }^{13}$. Her evocation of the pain caused by such quotidian essentialism takes seemingly inconsequential and widespread tropes to the level of individuated suffering. Thus, the purportedly 'positive' clichés of the French accent symbolising sexualised and intellectualised stereotypes in the collective imagination of the receiving society have more profound effects in the minds of the migrants to whom they are applied. This is confirmed by David Block's study on four French women teachers in London, who 'have all, at one time or another, been subjected to nationalistic and xenophobic comments' and 'have also found it wearisome to have to listen to stereotypes about French people eating frog legs and horsemeat' (Block 2006, p. 133). To understand how these prejudicial practices have become an invisible component of the postmigration London field, Bourdieu's conceptual toolkit is useful. In addition to the embodied 'habitus linguistique' (Bourdieu [1982] 2001, p. 113) of the migrants, we must consider how French accent stereotypes have become concretised and invisibilised in the diasporic field through their historicity (Blommaert 2010) and the habit/habituation components of the situated habitus (Huc-Hepher 2021, in press).

Bourdieu writes that in 'the relationship between habitus and field, history enters into a relationship with itself: it is a genuine articulation of ontological complicity' (Bourdieu and Wacquant 1992, p. 103) ${ }^{14}$. Through the sexualised framing of the French accent over centuries, therefore, the British public has become habituated to its loaded symbolic affordances. The very omnipresence and historicity of the symbolic power compounds its taken-for-grantedness, which in turn intensifies its insidiousness. Twentieth-century 'mediated cultural icons' (Sprio 2013, p. 151), like the femmes fatales of the French New Wave, Brigitte Bardot, Jeanne Moreau, Ana Karina, or their male counterparts, Jean-Paul Belmondo and Alain Delon, have crystallised the image of the hypersexualised French subject in the collective consciousness of the host population. And that imaginary was built on myths constructed in an earlier epoch, around eighteenth-century figures. These included the Marquis de Sade, whose notorious erotic lifestyle and works left an indelible mark on the English collective consciousness and language in the form of 'sadism'; and Louis $\mathrm{XV}$, whose libertine sexuality was rumoured among the influential circles of French aristocrats exiled in London following the French Revolution. We thus note a 'history

Original: 'je joue avec dans la caricature'.

2 Original: 'les gens mettent dedans un peu ce qu'ils veulent et souvent donc des stéréotypes'.

13 Original: 'je déteste généraliser vraiment, je déteste, parce que quand on me fait ça: "tu es française, donc...", "les Français, donc ... ", ça fait du mal'.

14 Original: 'la relation entre l'habitus et le champ, l'histoire entre en relation avec elle-même: c'est une véritable complicité ontologique'. 
made nature' (Bourdieu [1972] 2000, p. 263) ${ }^{15}$, whereby associations between Frenchness and sexuality have circulated in the diasporic field, been absorbed into local habituses and subsequently re-dispersed into the social space in the form of reductionist tropes, the symbolic force of which French migrants continue to endure.

While such stereotyping may be intended as a conscious expression of playfulness or irony on the part of the utterer, the humour, as discussed in my article on anti-French xenophobic microaggressions (Huc-Hepher 2019), is rarely experienced as such by the receiver. When forty-eight-year-old homemaker Chantal, a London resident of twenty-two years now living in South Kensington, recalled her former manager exclaiming " it must be really hard for you because you're so small, you're a woman and you're French"', the intersectional potency of the slur did not go unnoticed. Similarly, when sixty-three-yearold retired import-export administrator, Marie, who lived in Wandsworth forty years ago but has since relocated to Aix-en-Provence, was described as a 'bombe sexuelle' by her ex-husband's friends, she acknowledged the humoristic veneer, albeit conceding that the comedy was at her expense and made her feel 'a bit uncomfortable ${ }^{\prime 16}$. Rather than playful, therefore, the stereotyping of Frenchness, embodied through the distinctive accent, is borne as a subtle form of symbolic violence, whose historicity in the postmigration space contributes to its invisibility.

In this subsection, I have begun to demonstrate how mobility has given rise to a conversion in the symbolic rate of incorporated linguistic capital of the French migrants. By moving to a new national context and adapting to the language of the receiving society, the embodied inflections of their accent have taken on new, nationally embedded characteristics, perceived by players in the external field as indicative of prestige, sensuality and desire, but subjectively conceived in wholly oppositional terms. Further articulations of the lived experience of the French accent within the postmigration field are explored below.

\subsection{Embodied Symbolic Capital: A Differentiated Dialectic}

In this subsection, I examine the ways in which the French accent, as part of participants' linguistic habitus, assumes different symbolic affordances than those described above and how they are dependent on the migrants' individuated trajectories. In his chronicles of a London Frenchman (de Roquemaurel 2014), City banker Josselin de Roquemaurel recounts undergoing a phenomenon of embodied linguistic devaluation. There is no trace of the romanticised or sexualised symbolic 'value' of the accent noted by several of my research participants, including Sarah, who referred to it as an 'asset' suggestive of the 'romantic and literary image of French' in the postmigration field ${ }^{17}$. Rather de Roquemaurel recounts the painful and inherently corporeal frustrations of lacking sufficient linguistic capital to effectively convey his thoughts, particularly in the professional field, and the humiliation such deficiencies can bring. According to the author, in keeping with other members of London's French community,

they suffer from their accent in silence, like from an indelible birthmark. I personally experience this Gallic trait that deforms my language as a disability, a handicap far worse than a vice, because unlike many psychological defects, it is difficult to hide a vile accent. It adorns my thoughts and my words, it corrupts everything that escapes from my mouth, down to the most straightforward sounds or interjections ${ }^{18}$.

The vehemence, negativity and physicality of de Roquemaurel's words are arresting, and bear witness to the intensity of internal suffering caused by the lived experience of his

Original: 'histoire faite nature'.

Original: 'un peu gênant quand même'.

Original: 'un atout ... cette image romantique du français, puis littéraire'.

8 Original: 'souffrent en silence de leur accent, comme d'une tache de naissance indélébile. Je vis personnellement cet air gaulois qui travestit mon langage comme une infirmité, un handicap bien pire qu'un vice, parce qu'à la différence de nombreux défauts de l'âme, on peut difficilement dissimuler son vil accent. Il habille mes pensées et mes mots, il corrompt tout ce qui échappe de ma bouche, jusqu'à mes onomatopées et interjections les plus anodines.' 
accent in the diasporic field, even after twelve years of residency (de Roquemaurel 2014, p. 11). The dominant semantic field of the extract is one associated primarily with debility, recalling Blommaert et al.'s claim that even those 'with highly developed multilingual skills can feel, and be, communicatively incapacitated when they are "out of place"' (Blommaert et al. 2005, p. 198; my emphasis). From the 'indelible birthmark' to 'deforms', 'disability', 'handicap' and 'defects', the lexis peppering this relatively short passage is evocative of the bodily incapacity and profound discomfort the premigration accent, intrinsic to de Roquemaurel's primary habitus, instigates in the postmigration space. Rather than an outward symbol of romanticism or literary prowess, his 'vile' accent is inwardly endured as a distressing disorder. 'Worse than a vice', it is an innate (as per 'birthmark') infirmity over which he lacks agency ('escapes from my mouth'), its inevitability increasing his frustration and its corporeality exacerbating his emotions. He feels cheated by his own body ('corrupts'), his tongue remaining distinctly French, while his mind and outlook have been transformed through the migratory process.

Bourdieu contends that with considerable effort it is possible to alter a regional accent within the French (first) language, but its traces never fully disappear (Bourdieu 2005, p. 45; Levis 2016; Lippi-Green 2012; Baratta 2018; Szyszka 2020). And when attempting to erase a first-language accent in a second language, the challenge is multiplied, with the originary linguistic habitus susceptible to change only 'within the limits inherent in its originary "structure"' (Bourdieu 2005, p. 65), and neither the length of residence nor the age of onset (beyond childhood) play a significant role (Abrahamsson and Hyltenstam 2009; Marx 2002; Moyer 2011). Developing a second-language accent is a matter of powerful embodied structures, determined by the flexibility of the tongue and the sensitivity of the ear. Despite de Roquemaurel's desire to assimilate his Englishness to the bodily extent of his tongue, ultimately, he is unable to subvert this fundamental and intimate aspect of his primary French habitus. This in turn excludes him from full integration within the receiving society. Referring to his accent as 'self-discriminating' and an immediate marker of his 'foreign origin', de Roquemaruel confides that he feels like 'an outsider ... distinctly other, moving around in a hermetic ethnocultural silo' (de Roquemaurel 2014, p. 39) ${ }^{19}$. His French identity is reinforced in the postmigration space from the outside in, through his accent. Being a 'perceived-being who exists fundamentally through recognition from others' (Bourdieu [1982] 2001, p. 287) ${ }^{20}$, he undergoes a process of othering the moment an utterance is released from his mouth. For, as anonymous encounters in the diasporic field have led him to believe, 'Frenchness apparently perspires from [his] entire being' (de Roquemaurel 2014, p. 40) ${ }^{21}$.

Furthermore, in the same way that Bourdieu foregrounds the social implications of a regional accent within the French national context (Bourdieu [1982] 2001, pp. 126-31), so de Roquemaurel notes the sociosemiotic function of a French accent in the postmigration space, which compounds his sense of exclusion and inferiority. Bourdieu, himself the product of a region with a conspicuous nonstandard accent (and a distinct language), the markedness and symbolism of which took on greater meaning during his social and geographical mobility within France, notes that 'stigmates' (Bourdieu [1982] 2001, p. 282) can accompany certain linguistic traits ${ }^{22}$. Similarly, de Roquemaurel refers to his national accent as an 'immigrant's complex', issuing from 'the internalisation of the deviant accent's social stigma' (de Roquemaurel 2014, p. 86) ${ }^{23}$ within the situated context of the postmigration field. Both authors also bear witness to a correlation between a strong accent and intellectual inadequacy. Bourdieu emphasises the bodily prominence of "'guttural" accents' within the

19 Original: 'Mon accent, autodscriminant, trahit immédiatement mon origine étrangère' ... 'un étranger ... je me sens distictement autre, évoluant dans un isoloir ethnoculturel étanche'.

20 Original: 'être-perçu qui existe fondamentalement par la reconnaissance des autres'.

21 Original: 'La francité transpire apparamment de toute ma personne'.

22 Bourdieu's proficiency in Béarnais is evidenced throughout Le bal des célibataires (Bourdieu 2002), the markedness and symbolism of which took on greater meaning during his social and geographical mobility inside France.

23 Original: 'complexe d'immigré' ... 'l'intériorisation d'une stigmatisation sociale de l'accent déviant'. 
French social space, which by default negate the speaker's intellectual and professional standing (Bourdieu [1982] 2001, p. 129; Lippi-Green 2012)24. Likewise, de Roquemaurel notes an association between a 'non-orthodox accent and intellectual deficiency. Whether one you would need a knife to cut through in the south of France or simply a thick accent in the north, the stranger-strange accent is the mark of a mind that can legitimately be suspected of thickness (a thick mind)' (de Roquemaurel 2014, pp. 86-87; original italics) ${ }^{25}$. The inferiority complex to which de Roquemaurel refers is one that haunts him throughout his daily life as a migrant in London, pursuing him into the professional field, where he feels his pronounced accent belies the competence of his mind, 'How could a thick accent communicate refined and subtle thinking?' (de Roquemaurel 2014, p. 87) ${ }^{26}$, and where he fears being the subject of ridicule among colleagues (op. cit., p. 88). This process of perceived professional discrediting has been evidenced in other studies, where both first-language (Baratta 2018) and second-language (Derwing 2003; Levis 2016; Akomolafe 2021) accents have been shown to undermine competence, diminish respect and compound a sense of humiliation. For through the historicised habitus-capital-field-practice dynamic, it has become socio-culturally acceptable to deride Frenchness in its incorporated form as accent within the postmigration social space, as popular culture testifies. For example, the success of such 'thick-accented' national caricatures as the Pink Panther's Inspector Clouseau or the cast of the long-running BBC sitcom Allo, Allo! (de Roquemaurel 2014, p. 87) bears witness to the unseeing tolerance of this kind of trope. With accent discrimination being the 'last acceptable form of prejudice', "talking funny" (Akomolafe 2021, n.p.) is translated into funny talk for the purpose of localised (receiving society) entertainment, and thus "legitimately" derisible characters. Further, their (omni)presence in the postmigration mediascape (Appadurai 1990) helps to explain the transfer of such accented discrimination to the broader social space, where again the symbolic violence is often hidden behind a mask of humour (Huc-Hepher 2019).

However, an unforeseen dimension of the embodied experience of accent is its fundamental ambiguity. On the one hand, the loss of symbolic capital engendered by the accent and its reception is a burden internalised by the migrants in the diasporic field. On the other, as identified by de Roquemaurel, Bourdieu and several other participants, the symbolic transformation of their speech engendered through migration has had a liberating effect, allowing them to free themselves from the socioeconomic symbolic power of a local accent within the French national context. Indeed, the symbolic impedimenta of their originary linguistic habitus, so powerful in the premigration social space, is of no symbolic force in the postmigration context, as Catherine recounts:

I feel freer in England than I do in France ... You're both anonymous, because people don't know your background, there's not that burden of your accent ... but at the same time they notice you're foreign, because you've got that slight foreign accent in English ... a certain status ${ }^{27}$.

For Catherine, a fifty-three-year-old returnee, now teaching English in France, the symbolic transformation of her accent initiated through her transnational mobility is experienced positively. The regionally and/or socially nuanced inflexions of her accent, discernible by those encountered in the originary field, are converted into symbolic capital gains in the postmigration space, where the nationally defined connotations bestow a social status and socioeconomic anonymity previously denied. Surprisingly, de Roquemaurel identifies the same phenomenon, stating that migrating to London allowed him to 'leave behind the mental, familial and social structures of [his] country of birth' and enabled the

24 Original: 'les accents "grasseyants"'.

25 Original: 'accent non orthodox et carence intellectuelle. Qu'il soit à couper au couteau au sud, ou simplement épais au nord (a thick accent), l'accent étranger-étrange est la marque d'un esprit que l'on peut légitimement soupçonner de grossier ( $a$ thick mind)'.

26 Original: 'Comment un accent épais pourrait-il accompagner la communication d'une pensée fine et subtile ?'.

27 Original: Je me sens plus libre en Angleterre que ce que je me sens en France ... À la fois on est anonyme parce que les personnes ne connaissent pas nos antécédents, il n'y a pas le poids de l'accent, ... mais en même temps, ils remarquent qu'on est étranger, parce qu'on a un petit accent étranger en anglais ... un certain statut'. 
'freedom to evolve in a completely anonymous environment, where nothing [he] may have represented in France has the slightest significance here' $\left(2014\right.$, p. 164) ${ }^{28}$. While his final conclusion leans towards hyperbolic oversimplification, de Roquemaurel's acknowledgement of the place-specific hierarchies and limits of semiotic mobility across national and social spaces is nonetheless pertinent (Blommaert 2010). The 'social anchor' (Levis 2016, p. 153) provided by his accent in the premigration field is, as the author attests, rendered semiotically redundant in the postmigration space. Bourdieu posits that language, dialect and accent 'are subject to mental representations, that is, acts of perception and evaluation, knowledge and acknowledgement' (Bourdieu [1982] 2001, pp. 281-82; original italics) ${ }^{29}$, and these perceptions have been developed in particular placial contexts (Koven 2013). Devoid of the (French) cultural knowledge, then, the London population are typically unable to acknowledge the socio-culturally situated symbols of the migrants' primary linguistic habitus and this social anonymity is experienced as a liberating force.

According to Miranda, a twenty-eight-year-old doctoral student who migrated to London from a small village in the Aube region ten years previously, this anonymity was the aspect she enjoyed most about her mobility. For her, London represented:

being free, being able to be anonymous ... being able to speak another language. Not speaking your own language actually creates a kind of barrier that allows us to say what we want, and that's what I love ... In France, I think a bit more about what I'm saying. Here, I say to myself, yeah, go on. I can say what I want really, and with my poor accent they won't judge me, it'll be alright ${ }^{30}$.

While de Roquemaurel and Miranda both appreciate the sociosemiotic anonymity of migration, Miranda, unlike the former who experiences his accent as an impairment, finds her French accent to be a licence to utter thoughts unutterable-at least without careful consideration-in the premigration space. She subverts the traditional notion of language serving as a barrier impeding communication, conceptualising it instead as a barrier preventing the onset of the inhibitions of her native tongue (and thoughts). The diametrically opposed accounts of both migrants' internalised experiences of the intrinsic Frenchness of their accents could be explained by their differentiated migratory trajectories. Alternatively, they may have gendered undertones. For de Roquemaurel, although London constitutes 'a place of comfortable anonymity' (Favell 2008, p. 37), it simultaneously epitomises uncomfortable losses in symbolic capital caused by the traits of his linguistic habitus. Moving to London from a privileged position in French society, the symbolic depreciation undergone in the postmigration field is intensified by the shift it constitutes in relation to premigration 'mental representations'. That is, having been habituated to the positive connotations of his linguistic habitus within the premigration social space, de Roquemaurel arguably experiences his accent as a disability in the professional context of the postmigration field precisely because of the comparative linguistic intimidation perceived (Bourdieu [1982] 2001, p. 79) and the 'different, scale-sensitive indexicalities' (Blommaert et al. 2005, p. 214). Aware that 'the French accent can prove a handicap for the financial expert who needs to establish his professional credibility on the basis of symbols signalling the seriousness and importance of his position' (de Roquemaurel 2014, p. 88) ${ }^{31}$, he is also acutely aware of the downward status change the accent symbolises in relation to France. Cross-Channel symbolic capital conversion rates cause a perceived depreciation from in-group elite to incompetent Other. Contrastingly, in the premigration social space, Miranda's primary accent symbolises parochial paltriness as opposed to cosmopolitan

28 Original: 'sortir des structures mentales, familiales et sociales de [s]on pays de naissance' ... 'liberté d'évoluer dans un environnement complètement anonyme, où rien de ce je pourrais représenter en France n'a la moindre signification ici'.

29 Original: 'sont l'objet de représentations mentales, c'est-à-dire d'actes de perception et d'appréciation, de connaissance et de reconnaissance'.

30 Original: 'le fait d'être libre, de pouvoir être anonyme ... de pouvoir parler une autre langue. Ne pas parler sa propre langue, ça crée cette espèce de barrière, en fait, qui nous permet de pouvoir dire ce qu'on veut, et c'est ça que j'adore ... En France, je réfléchis un peu plus à ce que je dis. Ici, je me dis, ouais, allez. Je peux dire un peu ce que je veux, et avec mon pauvre accent, ils vont pas me juger, ça va aller'.

31 Original: 'l'accent français peut s'avérer un handicap pour le financier qui a besoin d'asseoir sa crédibilité professionnelle sur des symboles signalant le sérieux et l'importance de sa fonction'. 
credibility, given her origins in a rural setting in north-eastern France, known for its textile industry rather than its financial services. Through mobility, she experiences an upward symbolic capital exchange rate. The associations of the premigration space are replaced by an empowering anonymity that affords her the confidence to embark not only on an undergraduate degree in London, but subsequently doctoral studies-something she had never envisaged in France.

Each migrant's initial habitus and migratory journey consequently influence their experience of the (non)standard accent, in the same way that their gender is inextricably implicated. Bourdieu posits that adopting the accent of those in positions of dominance, in this case the 'host' population, involves a double negation of the speaker's virility, 'because the very fact of acquiring it requires submissiveness and ... this submissiveness encourages dispositions which are themselves perceived to be effeminate' (Bourdieu [1982] 2001 , p. 130) ${ }^{32}$. According to this paradigm, de Roquemaurel's inability to accommodate his speech to the standard 'norm' (Giles et al. 1973; Giles and Johnson 1987) points to subconscious resistance to submit to the 'foreign' virile forces; not a deliberate assertion of his Frenchness per se but a subtle assertion of his (male) identity nonetheless. He writes that '[m]y surname [is] completely unpronounceable for the average Englishman [ ... and] my first name [Josselin], being generally used to baptise girls, ... really doesn't help me to integrate' $(2014, \text { p. } 39)^{33}$. Given the effeminising othering prompted by his name alone in the postmigration field and the corporate workplace forces that impose a Western [or in this case, English] cultural identity [ ... and] cultural dominance on workers' (Nyobe and Plane 2020, p. 5), itself enmeshed with the intertwining notions of capitalism, colonialism, whiteness, masculinity/virility and monolingualism (Phipps 2020; Huc-Hepher), de Roquemaurel's accent nonaccommodation thus serves as a mechanism to push back against these everyday intersectional slurs and 'linguistic-based prejudice, perceived though it may be, [that] still exist[s] in the British workplace' (Baratta 2018, p. 7).

Conversely, Miranda's newfound comfortableness within her accent in the postmigration space, resonating with the 'status' referred to by Catherine, gives rise to an openness to the dominant linguistic field forces and a willingness to embrace them. This receptiveness, which is doubtless a reflection of the non-judgemental reception she encountered in the diasporic field, means she not only deploys her accent as a tool for uninhibited free speech, but she has physically submitted to the English language, opening her ears and adapting her tongue to adopt a highly convincing English accent ${ }^{34}$. It is also telling that Miranda's chosen field of specialism for her doctoral studies at UCL is ... linguistics.

From these testimonies, we have seen how accent functions as an internalised dialectic, the symbolic worth of which varies across the transnational space (Blommaert 2010; De Fina and Perrino 2013). On one hand, it served as a barrier to inclusion, on the other, as a liberating and anonymising force, neither of which tally with the French accent as a mythologised signifier of sex appeal and prestige in the collective host imaginary, nor with the semiotic affordances of the participants' primary linguistic habitus in the premigration field. For de Roquemaurel, mobility incurred a loss in embodied symbolic capital at odds with the sense of positive anonymity experienced postmigration. Whereas migration generated linguistic capital profits for Miranda and Catherine at odds with the symbolic burden of their accent pre-migration. This simultaneously incapacitating and empowering function of accent was closely dependent on the migrants' individuated trajectories and their social and gendered positioning. Its centrality to their identity and sense of fulfilment in the diasporic field were thus ascertained. In the following subsection, I further interrogate the role of language in relation to identity and belonging, examining how the migrants'

32 Original: 'parce que le fait même de l'acquisition demande la docilité ... et ... cette docilité porte vers des dispositions elles-mêmes perçues comme efféminées'.

33 Original: 'Mon nom de famille [est] complètement imprononçable pour un Anglais moyen [ . . . et] mon prénom, étant en général employé pour baptiser des filles, ne m'aide vraiment pas à m'intégrer.'

34 It could be argued, however, that Bourdieu's association of linguistic submission and docility with innately feminine characteristics is itself inherently misogynistic and outdated. 
spontaneous translanguaging practices can both enhance and compromise embedding, depending, once again, on situatedness within the transnational context (Blommaert 2010; De Fina and Perrino, 2013).

\subsection{Embedded Symbolic Capital: Translanguaging across the Transnational Space}

Translanguaging is a practice with which all my research participants identify, together with de Roquemaurel at some length (de Roquemaurel 2014, pp. 90-94). Given this prominence and my own participant observations of widespread translanguaging, in this subsection I investigate its varying symbolic weight according to the situatedness of its expression. I argue that, despite some participants experiencing their spontaneous London-French vernacular negatively, due to the status awarded to standard French in the premigration field (Doran 2004; Harrison and Joubert 2019) and to the identity loss translanguaging can represent for them personally (Marx 2002; McCrocklin and Link 2016), it should not be apprehended in dispositional hysteresis terms. On the contrary, in keeping with much of the literature (MacSwan 2017, p. 191; Cacciatore and Pepe 2019; Seloni 2019), I contend that participants' pre-reflexive translanguaging practices typically play a positive symbolic role in London, where they enhance in-group belonging and contribute to the construction of a community identity. However, echoing Koven's analysis of contested models of emigrant personhood (Koven 2013), my findings also bring to light a process of symbolic capital conversion whereby the beneficial affordances of translanguaging are compromised when transferred to the premigration space. I show how the migrants' localised vernacular functions in an exclusionary manner, adopting a veneer of symbolic distinction when articulated outside its habitat (i.e., London), being (mis)conceived as an agentive sociocultural stratification mechanism and resulting in a form of misplaced out-group 'reverse othering'.

Robert illustrates the in-group community-building function of London-French translanguaging, underlining the situated 'common-unity' of spoken practices (Cox 2005; Li 2011, 2018; Wenger 1998, 2004; Cacciatore and Pepe 2019) and their contribution to a shared London-French linguistic habitus. He relates how:

we can quite easily begin in French and end in English, or come out with an English expression that we'll all understand because it doesn't really translate into French, or because it sums up either the sentiment or the remark. And we do that quite a lot. Or it might even be just using a single English word in a French sentence. It's quite odd, and anyone listening - anyone French listening - would take us for a bunch of lunatics because it's French mixed with English ${ }^{35}$.

It is precisely the exclusivity of this emergent London-French 'vernacular' that gives it symbolic value among the London-based diaspora. Likewise, it is precisely Robert's 'core identity' (Baratta 2018, p. 17) that underpins his reference to the speakers of the vernacular as 'a bunch of lunatics'. While such nonstandard translanguaging is a common feature of the postmigration habitat-in myriad language combinations-, because Robert's habitus has been shaped in an external field where standardised French and a monolingual norm are institutionally prescribed, both vertically and horizontally ${ }^{36}$, he perceives his own evolving linguistic repertoires to be 'abnormal' and irrational. However, he also recognises their distinctive, in-group potency. Robert's reference to 'anyone French listening' implicitly distinguishes him and his London-French acquaintances from the non-migrant, predominantly monolingual French population, while cementing the migrants' group

35 Original: 'on peut très bien commencer en français et terminer en anglais, ou sortir une expression anglaise qu'on va tous comprendre parce qu'elle se traduit pas vraiment en français, ou parce qu'elle va résumer soit le sentiment ou la remarque. Et on a tendance à faire ça. Ou même ne serait-ce qu'à utiliser un seul mot anglais dans la phrase française. C'est assez particulier, et les gens qui nous écouteraient-les Français qui nous écouteraient-nous prendraient pour des tarés, des fous, parce que, oui, c'est un français mélangé avec de l'anglais'.

36 Vertically: that is, from school upwards; examples of which include the fierce opposition to Arabic teaching in French schools, semi-colons being advised against on French governmental websites and ongoing debates surrounding the absence of France's regional languages in the education system, in spite of popular support in some regions. Horizontally: that is, by way of the national and worldwide institutions promoting and protecting the French language, as discussed at the beginning of this article. 
membership and London-French identity. He refers to French guests visiting London as 'les Français' and admits that while his London-French circle of friends 'are French ... we don't consider ourselves as truly French: we're a mix ${ }^{\prime 37}$. The fluid linguistic repertoires he describes, whose embeddedness in the postmigration discursive space e(xc)ludes FrancoFrench listeners, affirms the migrants' shared London-French linguistic habitus, which in turn reinforces their collective identity as members of the French community in London, despite many participants' cognisant rejection of such an epithet (Huc-Hepher 2015). In the same way that the verlan of the Paris suburbs 'can be viewed as an alternative code which stands both literally and figuratively outside the hegemonic norms of Parisian culture and language' (Doran 2004, p. 94), or that the translanguaging of Italian migrants in London serves 'to strengthen the cohesion of the new group, which is so heterogeneous to deny its community nature, and to find common grounds to reflect on their new migratory identity (Cacciatore and Pepe 2019, p. 521), so the London-French dialect functions dynamically as a mechanism for symbolic belonging (inclusion) and sociocultural distinction (exclusion) (De Fina 2006; Koven 2013).

Laura, a forty-one-year-old stockbroker-turned-singer-songwriter, originally from Paris but now a Clapham resident of five years, confirms the existence of 'a new sort of London franglais' ${ }^{38}$. She initially turns to her children for examples of lexical borrowing, mentioning that her daughter might say ' $c$ ' est où mon sac pour le swimming pool? [where's my swimming pool bag] or her son who typically has to 'practise mon violon'. But Laura soon reflects on her own translanguaging practices and those of other London-French parents whose originary linguistic habitus is more entrenched, yet still susceptible to change under the prolonged pressure of the local field. The example she provides is the use of the English term 'l'auction', pronounced in standard French form, preceded by a French definite article and inserted into a French phrase, rather than using the standard equivalent: 'la foire aux enchères'. Like her son's usage, this is doubtless the result of economy of effort within the situated context and in-group circle of the diasporic school. Miranda's phonological experience of this emerging London-French vernacular, however, contrasts Laura's Frenchinflected examples and sheds light on the operationalisation of intonation as an additional symbolic marker surpassing the intentions of the speaker:

there's a lot of what we call 'code-switching' [said in English]; it's easy to communicate with a lot of my friends because we do it without thinking ... Cognitively, it's easier, the words often come quicker in English ... But that happens in all communities. Even when we speak French, but use an English word, we'll immediately put an English intonation and sounds on it ... Actually, the sounds come to me automatically, they're established in my phonetic space in English. Even just saying 'OK' [with a French accent], is an effort —it's funny. It took my family a long time to realise that I find it difficult ... Sometimes I come out with French words that are half English: the other day instead of saying 'to plan' in French [planifier], I said 'planer' [based on the English word, but meaning to glide in French]. I often invent things like that ${ }^{39}$.

Here, we note Miranda's background in linguistics informing her narrative. Yet, it is pertinent that what she dismisses as commonplace diasporic 'code-switching' is indeed a more complex form of translanguaging (Blommaert 2010). For beyond the bilingual lexical merging of French and English, her language practice testifies to the function of intonation and pronunciation as a symbol of postmigration embedding, and to the creative impulses

37 Original: 'on est français, mais on ne se considère plus vraiment français: on est un mélange.'

38 Original: 'une nouvelle sorte de franglais londonien'.

39 Original: 'il y a beaucoup de ce qu'on appelle 'code-switching'. C'est facile de communiquer avec beaucoup de mes amis parce qu'on ne réfléchit pas en fait ... De manière cognitive, $c^{\prime}$ est plus facile, les mots viennent souvent plus facilement en anglais ... Mais ça, ça se passe dans toutes les communautés... Même quand on parle en français, mais utilise un mot anglais, tout de suite on va mettre une intonation et des sons anglais ... Les sons ils me viennent automatiquement en fait, ils sont établis dans mon espace phonétique en anglais. Même juste de dire 'OK' [pronounced with a French accent], c'est un effort - c'est marrant. Ça a pris longtemps pour que ma famille se rende compte que j'ai du mal ... Des fois je sors des mots français à moitié anglais: l'autre fois au lieu de dire 'planifier', j'ai dit 'planer'. J'invente des trucs comme ça souvent.' 
stemming from that positioning. Thus, beyond the French/English dichotomy implied by 'code-switching', we observe how other modes are implicated in the translanguaging act (intonation) and how new terms emerge from Miranda's transnational positioning ('planer'). Rather than switching between the languages, Miranda merges them intuitively, multimodally and generatively (Li 2018). She 'automatically' calques English 'sounds' onto English words used within French contexts and transforms the English verb 'to plan' into a French regular -er verb 'planer'. In this way, she substantiates Li Wei's assertion that 'Translanguaging is a transformative, resemiotization process, whereby language users display the best of their creativity and criticality ... which conventional code-based approaches cannot address' (Li 2018, p. 22). Underlining this 'Translanguaging Instinct' (Li 2016), Miranda admits to the cognitive ease of such fluid languaging in comparison to linguistically compartmentalised speech, which is out of kilter with her lived transnational experience, situated in the productive in-between space of both languages, cultures and nations. Similarly, in keeping with the 'framing [of] Translanguaging as a practical theory of language' (Li 2018, p. 10), it is telling that Miranda pre-reflexively refers to 'code-switching' in English, thus playing out the practice to which she alludes, and subsequently to 'communities', thereby intuitively performing the community belonging that her localised vernacular has prompted.

In keeping with Miranda and Robert, thirty-four-year-old foreign correspondent, Charles, attests to the creative force of pre-reflexive translanguaging. But he counterbalances this positive dimension with the symbolic capital losses that can arise from it outside the transnational social space. He explains that a conscious effort needs to be made to prevent English words from seeping into his French radio reports, because in addition to semantically distancing his audience, such translanguaging would coat his speech in an unintended symbolic layer of pomposity:

when commentating on the radio [in French], I always have to be careful not to slip in any Anglicisms, because you begin to get certain habits. It's sometimes seen as a form of snobbery when you're in France. There are some words that come more easily, and it means we're always seen as if we're showing off a bit ... It's true that things get mixed up and it can sometimes be easier to express yourself in English. We use a lot of terms like that; for example, when sending an email we'll say we're going to 'forwarder' it. It's not snobbish at all, but there is a sort of franglais developing ${ }^{40}$.

Charles's example of translanguaging's generative capacity resonates closely with Miranda's: 'to forward' in English intuitively becomes the regular -er verb 'forwarder' in the London-French vernacular in the same way that 'to plan' became 'planer'. Similarly, de Roquemaurel alludes to equivalent -er London-French neologisms: 'updater', 'driver' and 'checker' (de Roquemaurel 2014, p. 92) to exemplify an emerging 'créole franco-londonien' (op. cit., p. 93). This shared grammatical transformation of everyday English verbs according to the same (London-)French method again bears witness to the common-unity of translanguaging practice in the postmigration space and hence discursively strengthens in-group belonging. An unsaid recodification system binds the migrants together in a community of linguistic practice, just as it does the Italians in London, whose '[t]ranslanguaging thus becomes a practice, a means to signal commonality of experiences' (Cacciatore and Pepe 2019, p. 520). However, at the same time, inadvertent translanguaging in the premigration space triggers a process of unmotivated symbolic transformation. As Charles describes, there is a disconnect between the intuitive ease which determines his habituated use of English terms and the way in which it is perceived by French non-movers.

40 Original: 'en commentant à la radio [française], je dois toujours faire attention de ne pas glisser quelques anglicismes, parce qu'on commence à prendre certaines habitudes. Parfois c'est vu comme une forme de snobisme quand on est en France. Il y a certains mots qui peuvent arriver plus facilement, et ça, toujours on est vu comme si on se la jouait un petit peu ... C'est vrai que les choses se mélangent et ça peut être plus facile de s'exprimer parfois en anglais. C'est vrai qu'il y a beaucoup de termes comme ça qu'on utilise; comme par exemple quand on envoie un e-mail, on dit qu'on va le 'forwarder'. C'est pas du tout du snobisme, mais il y a une sorte de franglais qui se développe.' 
Confirming Bourdieu's 'perceived-being' notion, the same translanguaging that serves to connect the migrants in London functions as a divisive force in France.

Moreover, it is a form of negative symbolic capital conversion endured by many other research participants, who refer to French non-movers' perceptions of their translanguaging as 'snobbery', 'super snob', 'ridiculous', 'mental', 'mad', 'showing off', 'bragging', a 'little English act', and so on. It is also a phenomenon shared by other diasporic communities; for example, Koven contends that Portuguese non-movers 'may read emigrants' French and its links to status as illegitimate, inauthentic, and pretentious' (Koven 2013, p. 328; original emphasis). Such external perceptions contrast starkly with the migrants' internal perspective on their spontaneous linguistic repertoires, which compounds the sense of inner and outer estrangement. Indeed, as illustrated by Brigitte, a thirty-five-year-old post-doctoral molecular neuroscientist from Lyon, who has lived in Bethnal Green for three years, the symbolic transformation of her diasporic translanguaging in the premigration space is by no means indicative of the internalised challenge that resisting it constitutes:

it's hard for me; doing presentations is the worst, I mean, speaking French professionally-it's a catastrophe. I can't find the words, so it comes over as super snobby, so everyone thinks you're showing off a bit, but actually, not at all, it also looks pretty ridiculous! ${ }^{41}$

Inwardly, struggle and humiliation dominate Brigitte's discourse ('hard', 'catastrophe', 'can't find', 'ridiculous') just as they did Miranda's, who alluded to the 'effort' and how 'difficult' it was to respect the linguistic borders of French and English. This internalised strain is accentuated by the comparative ease of relinquishing oneself to the intuitive pull of translanguaging, as Miranda's testimony confirmed: 'it's easy to communicate with a lot of my friends because we do it without thinking', and Charles's: 'words that come more easily'. Such ease can be explained by the fact that, as Li Wei posits, '[w]e do not think in a specific, named language separately' (Li 2018, p. 18), rather, 'we think beyond the artificial boundaries of named languages in the language-of-thought' (op. cit., p. 19). Undermining the notion of a cognitive 'switch' when moving between languages, the notion of a fluid internalised idiolect that disrupts abstract boundaries and reduces the cognitive load of discrete languaging, better reflects the lived experience of my participants' transnational translanguaging (Blommaert 2010; García and Otheguy 2014; Otheguy et al. 2015).

Intuitively engaging in this nascent vernacular with other members of the diaspora in the postmigration space, without the need for explanation or standardisation, also means it is equated with implicit in-group understanding and ease, in contrast to the unease associated with the migrants' attempts to restrain it in the premigration space and remain within the rigid frameworks of named languages. Indeed, as a young and ambitious neuroscientist, Brigitte's frustrations at being confronted with lexical gaps in the French language in the French scientific field are reminiscent of the internalised anxieties provoked by de Roquemaurel's perceived 'thick accent' in the finance sector. Through an unwitting process of symbolic alchemy (Bourdieu 1994, p. 184), her English linguistic capital, which she perceives as a deficit in this professional context due to its encroachment on her native lexicon, is transfigured, purportedly becoming a symbol of feigned elevated social status and in turn derision in the minds of the listeners. For, just as Bourdieu contends, the manner in which one speaks, in other words the symbolic value of the delivery, typically takes precedence over the subject matter (Bourdieu [1982] 2001, pp. 160-61).

Outwardly, therefore, Brigitte's and the other migrants' organic translanguaging adopts new symbolic affordances when resistance is attempted in the originary social space. In France, rather than an economic in-group vernacular, it is perceived as an affected form of social distinction, alienating the migrants from French 'stayers' (Favell 2008, p. ix; Braun and Arsene 2009). On a subconscious level, the symbolic loss incurred through the (mis)interpretation of the translanguaging as a deliberate articulation of newfound

41 Original: 'c'est dur pour moi; le pire c'est quand il faut faire des présentations, enfin au niveau professionnel en français - c'est une catastrophe. Je trouve pas de mots, donc ça fait super snob, donc on croit tous qu'on se la pète un petit peu, mais en fait pas du tout, ça parait très ridicule aussi!' 
superiority could be a corollary of the resentment felt by those left behind, some of whom suffered their loved-ones' departures as 'hidden injuries' (Lehmann 2013, p. 9). For them, the migratory act is not only conceived as a personal rejection, for example a desire to sever, or at least distance, filial ties, but equally a form of symbolic differentiation, the London-French's geographical mobility functioning as perceived social mobility, or 'snobbishness', through their exposure to, and embodiment of, 'strange' - and potentially superior-practices (Koven 2013; Cacciatore and Pepe 2019). In a dynamic symbolic process, my research participants' decision to migrate, to reject the habitat of origin, has caused a shift in their cultural and linguistic capital, transforming their dispositions and in turn subverting their originary habitus. This linguistic habitus transformation, demonstrated powerfully here by the altering relationship to and deteriorating mastery of their mother tongue, 'has seen them move increasingly further away from their old self, their family, and their old peer group and arrive at a destination that is better, desirable, and ... as part of this transformation of habitus, the "old" has become foreign and dislocating, while the "new" is now familiar and reassuring' (Lehmann 2013).

The 'hidden injuries' are therefore felt on both sides, by the movers alienated from the once familiar linguistic space of their originary habitat, and by the stayers who feel cheated and socio-culturally inferior: although the migrants, now linguistic and 'cultural outsiders' (Lehmann 2013, p. 12), 'have moved on and improved themselves, old peers (and perhaps family) are seen as "stuck"' (Lehmann 2013, p. 12). This is demonstrated by Robert, whose parents experienced his mobility as a 'betrayal' and his friends as 'abandoning' them ${ }^{42}$, as well as Miranda, whose childhood friends 'think she has become big-headed in relation to them', but from her perspective 'nothing has changed', she does not 'consider them inferior' and she 'will always hold them dear' 43 . Underpinning the symbolic devaluation in the migrants' linguistic capital in the premigration space, then, is the affective potency of migration, the discrepancy between stayers' and leavers' perceptions, and the situatedness of semiotic affordances (Blommaert 2010). Despite the generative fluidity and cognitive ease of translanguaging, inflexible dichotomies continue to dominate outside the diasporic space: us/them, inner/outer, pre/postmigration. Indeed, Block describes how one LondonFrench migrant, on return visits to Bordeaux, 'makes a point of meeting up with them [childhood friends], [but] she nonetheless erects a wall of sorts between their lives and hers' (Block 2006, p. 130). The persistence of such boundaries therefore casts doubt over the effective border-breaking capacity of translanguaging, a theme interrogated in the following subsection.

The accounts shared in this subsection have demonstrated the symbolic borders of the transnational, translingual space. Detached from the parochial Frenchness of their primary habitats through their transformed linguistic habitus, my research participants emerge, in practice, as a collectivity apart. Through their fluid translanguaging and the birth of a London-French 'Franglais' (de Roquemaurel 2014, p. 92), they find themselves disconnected from 'host' and 'home' populations. On the one hand, in the premigration social space, their 'hybrid speech is not [perceived as] the inevitable consequence of life abroad, but reveals disloyalty to the homeland' (Koven 2013, p. 328). On the other, they are interconnected in the postmigration space through an implicit bond which defies linguistic and national divides (Sheringham 2010; Beswick 2020). Consequently, despite conceptualising the 'French community' as a South Kensington elite to which they do not belong, they have, as discussed in this subsection, brought to bear a shared geographically, linguistically and symbolically defined identity, in other words, a London-French 'community'. This resonates with the operationalisation and effects of translanguaging among other European migrant communities, such as the Italians in London (Cacciatore and Pepe 2019) and Toronto (Di Salvo 2017), the Spanish and Portuguese in Bournemouth (Beswick and PozoGutiérrez 2010) and Jersey (Beswick 2020) and the Portuguese in Paris (Koven 2013),

42 Original: 'une trahison' ... 'tu nous laisses tomber'.

43 Original: 'pensent que j'ai pris la grosse tête par rapport à eux' ... 'ça ne change rien pour moi' ... 'je ne les considère pas moindre' et 'je les aimerai toujours'. 
for whom, rather than exclusively emplacing or displacing them in/from the pre- or postmigration place, their hybrid languaging situates them in a 'polycentric' transnational space (Blommaert et al. 2005, p. 200) and 'at some point along a continuum on which their patterns of accommodation into the receptor society vary' (Beswick and Pozo-Gutiérrez 2010, p. 59).

In the following and final subsection, I take this transnational and translingual positioning a step further and ask whether the complex repertoires, (self-)identifications and spatialities implicated in London-French languaging take us beyond the notions of the 'cleft habitus' (Bourdieu 2004), of linguistic hybridity (Li 2018) and even the 'hybrid habitus' (Decoteau 2013; Pulley and Whaley 2020), to a post-structural 'third space' (Bhabha 1994) that transcends traditional dualisms and, as such, reflects the more porous lived experience of the migrants.

\subsection{Beyond a 'Cleft' or 'Hybrid' Habitus? Testing the Limits of the Translanguaging Third Space}

In the previous subsection, we began to see how participants' spontaneous translanguaging practices served as a symbolic barrier to inclusion in situated migration spaces. In this final subsection, I interrogate the implications of diasporic translanguaging further, exploring the ways in which the transnational linguistic space interacts with the migrants identity construction and reflects the in-betweenness of the migratory experience. Li Wei posits that the 'Translanguaging Space acts as a Thirdspace which does not merely encompass a mixture or hybridity of first and second languages; instead it invigorates languaging with new possibilities' (Li 2018, p. 24). Such creative potentiality has been evidenced above, as has the boundary-breaching affordances of London-French migrants' linguistic repertoires. However, the degree to which, on an individuated level, participants experience this translanguaging space as an idealistic third space 'that innovates and interrupts the performance of the present' (Bhabha 1994, p. 10) remains to be seen. Their narratives could equally bear witness to a disorientating in-between space conducive to hysteresis (Bourdieu [1972] 2000; Hardy 2012) and contested identities (Brah 1996), resulting in a 'painfully fragmented self' (Friedman 2016, p. 110) in the form of a cleft habitus (Bourdieu 2004). However, based on the argument that translanguaging leads to self-identifications and belongings that 'are not necessarily divided, since inherent and "borrowed" qualities and traits are not mutually exclusive' (Beswick and Pozo-Gutiérrez 2010, p. 44), it is also plausible that the migrants experience both of these states depending on the situational and interpersonal context. For, as Bourdieu famously contends, reality is relational (Bourdieu 1994, p. 17).

As we have seen, the habitus of many French migrants begins to succumb to the pressures of the postmigration field over time. For some-and at certain points in their narratives-this slow but steady process of culturo-linguistic transformation has positive implications. Robert, for example, alludes to the cosmopolitan identity that living in a superdiverse global city (Vertovec 2007) forges:

Maybe we feel a bit more international because we live in London. So we all have a lot of friends who come from Europe, but from elsewhere too, and thanks to those friends, we don't feel as French: not necessarily European, but global ${ }^{44}$.

This transformed, distinctive and positive sense of self is also experienced by Brice, who recounts being 'at home' in his newfound linguistic habitus: 'I feel more at ease here in general, in the English language, in the English culture', and for him, French is now his 'holiday language ${ }^{45}$. However, as touched on above and further examined below, this culturo-linguistic wellbeing comes at the risk of disidentification from France and can give rise to a disorientating sense of displacement reminiscent of 'habitus hysteresis' (Bourdieu [1972] 2000, p. 278), that is, 'the disruption between habitus and field' (Hardy

44 Original: 'On se sent peut-être un peu plus international parce qu'on habite à Londres. Donc on a tous beaucoup d'amis qui viennent d'Europe, mais aussi d'ailleurs, et grâce à ces amis là, on se sent pas aussi français: pas européen nécessairement, mais mondial'.

45 Original: 'je me sens plus à l'aise ici en général, dans la langue anglaise, dans la culture anglaise' ... 'langue de vacances'. 
2012, p. 127; original emphasis). In both cases, the relationship between language and identity is fundamental, for ' $[w]$ ithout access to language there is no access to the symbols necessary for thinking and acting as a self in a structured world of symbolic meaning (Elliott 2008).

Corresponding more to the concept of the advantageous hybrid habitus than the painful cleft habitus, several participants report taking on different characteristics according to the language they are speaking. It is a process identified among many other bilingual groups, and one, as argued by Koven, where migrant identities are not only expressed through their language but emerge from it, in 'verbal enactments of identity' or 'selves in two languages' (Koven 2007, title page). This is the case for both Robert and Séverine, a fifty-year-old lawyer, originally from Paris, but who migrated to London twenty-six years ago and now calls Nunhead home. She confides that 'When I speak French and English, I'm not the same person, absolutely not ... I'm immediately a little more sophisticated with French, a little more, almost snobbish, and then my voice, my pitch is higher than in English $^{46}$. Not only does Séverine adopt different named languages when navigating the linguistically complex transnational space, but, in line with the inherent multimodality of translanguaging (Kress 2010; Li 2018), the timbre of her voice shifts as an embodied signifier of (premigration) social standing. Her translanguaging therefore carries cultural and social symbolic weight that transcends the lexical, syntactic and national boundaries of the named languages and instead corresponds to her more pliable transnational habitus, transmuting in concert with the linguistic/social space (Seloni 2019). Importantly, Séverine's words bear a striking resemblance to Robert's, who has 'the impression of being a different person when I speak English and French. There's another personality I discover in myself: I'm a bit more talkative, more at ease, less shy in that language [English], which is strange ${ }^{47}$. In spite of the strangeness observed, speaking English in the postmigration field has a positive impact on Robert's selfhood and appears to embody a priori the concept of the 'reconciled habitus', whereby a 'person can successfully navigate both fields ... accommodate both structures despite opposition [and] [c]an induce a degree of reflexivity' (Ingram and Abrahams 2016, p. 148). Thus, in this example, Robert's transformed habitus is consistent with the 'optimistic concept' of the third space (op. cit., p. 141), but it is telling that he continues to make a distinction between the language/habitus of premigration and postmigration fields. The endurance of such dualisms gestures towards hybridity rather than a wholly post-structural, transnational and translingual ideal, albeit a hybridity whose inherent plasticity enables it to morph according to the geographical and linguistic situation. Rather than doing so agentively, however, as accommodation theory presupposes (Giles et al. 1973), I argue, drawing on Blommaert et al. (2005), that the space is also agentive: 'agency results from the interplay between people's situated intentions and the way the environment imposes particular regimes of language' (Blommaert et al. 2005, p. 211; my emphasis) and 'imposes requirements on us which we may fail to meet' (Blommaert et al. 2005, p. 211, 198). It is significant, therefore, that both Robert and Brice spontaneously refer to being 'at ease' in the English language, since this sense of ease is typically ascribed to the primary habitus, the premigration space and the first language, where everything 'takes place as second nature' (Bourdieu [1972] 2000, p. 263) due to the 'fish in water' (Bourdieu and Wacquant 1992, p. 103) effect of the originary habitat ${ }^{48}$. That both participants now associate being 'at ease' within the postmigration translanguaging space consequently suggests that longterm immersion therein has contributed to a productive redefinition of their internalised linguistic habitus and an externally generated recalibration of 'home' (Beswick 2020).

This is pertinent, for as Bourdieu [1982] (Bourdieu [1982] 2001, p. 287), Elliott (2008, p. 30) and Baratta (2018) argue, 'identity is a two-way street' (Baratta 2018, p. 9), not only

46 Original: 'Quand je parle le français et l'anglais, je ne suis pas la même personne, absolument pas ... Je suis tout de suite un peu plus sophistiquée avec le français, un peu plus, presque snob, et puis ma voix, mon registre est plus élevé qu'avec l'anglais'.

47 Original: 'l'impression d'être une personne différente quand je parle en anglais et français. Il y a une autre personnalité que je découvre en moi: je suis un peu plus loquace, plus à l'aise, moins timide, en fait, dans cette langue [1'anglais], ce qui est étrange.'

48 Original: 'réalisée dans une seconde nature' ... 'poisson dans l'eau'. 
defined by external-internal dynamics, but as much by others as by the self. As such, the reduction in the sensation of shyness perceived by Robert when speaking English, and the ensuing sense of being at ease or at home in the linguistic space, could be a direct corollary of the reduced intimidation encountered in the postmigration field, just as Séverine's intonated 'snobbishness' in French is a reflection of the symbolic expectations of the premigration field. For, as Bourdieu conjectures, 'timidity resides in the relationship between the intimidating situation or person ... and the intimidated person' (Bourdieu [1982] 2001, p. 79) ${ }^{49}$. Robert's transformed linguistic habitus allows him to cast aside the positioning of exclusion and victimisation to which he was accustomed in the premigration field, where he was intimidated simultaneously by his family's modest socioeconomic circumstances and his (reproached) sexuality. The 'less shy' and 'more talkative' dispositions that Robert associates with speaking English are therefore consistent with the ease experienced in his liberated transnational subjectivity and spatiality.

Although the narratives examined above led us towards a utopian third space, performed by the comfortable inhabiting of the English language and the easy embracing of two linguistically shaped personalities, the migrants' framing of these selfhoods in dualistic terms to some extent undermines the 'trans' ideal and accentuates the hybridity of their evolving habitus (Decoteau 2013; Pulley and Whaley 2020). Not encapsulating a cleft habitus per se, the migrants' identities nonetheless remain in 'flux' (Elliott 2008, p. 140), susceptible to the pressures exerted by the postmigration field. This becomes no more apparent than when participants are confronted with the translanguaging practices of their progeny. Margherita Sprio writes that '[f]luency of language is often the marker through which cultural identity is negotiated, and lack of entry into language through non-fluency is still a way to differentiate between assumed 'true' assimilation and a more partial one' (Sprio 2013, p. 227). In an inversion of this framework, which tallies with the reverse othering some migrants experience when translanguaging in the premigration space (discussed in the previous subsection), for some participants, witnessing their children's lexical and phonological lacunae in the 'mother' tongue can represent a painful division, their 'own flesh and blood' being only a partial incorporation of themselves.

Return migrant, Marie, recalls vividly the physical repulsion caused by her children's increasing English and decreasing French linguistic capital: 'At one point, my children couldn't speak French any more, and then, really, I freaked out. I was sickened. It was important, for example, for my mother who couldn't speak English. So I sent them to French school ${ }^{50}$. Like for the Spanish migrants in Beswick and PozoGutiérrez's study, attending mainstream English school and the increased proficiency that such immersion brings, simultaneously results in 'loss of Spanish as the mother tongue' (Beswick and Pozo-Gutiérrez 2010, p. 51). Yet, Marie experiences her children's loss of French as a personal loss, almost a second postpartum rupture, the severance being a symbolic estrangement, as opposed to a physical separation, but no less powerful for it. The sense of distress is heightened by the linguistic capital deficit threatening the maintenance of filial ties and a shared way of perceiving the world: 'a language is a whole state of mind, so if you don't speak it, that way of thinking fades away' ${ }^{\prime 5}$. This sentiment echoes Block's findings, whereby 'core French national/cultural identity, which is tied to the French language [ . . , ] is not invulnerable and can be lost' (2006: 121). Reiterating Marie's experience, it was a reference to a London-French mother as " "mum" instead of "maman"' that 'really schocked' Block's informant, because "'maman" is a magic word, whereas "mum", it doesn't mean anything', being 'an inheritance' rather than 'the primary language of ... affiliation' (2006: 121). Sarah expresses similar concerns when discussing her daughter's (French) language use: 'you have to insist, otherwise it disappears ... I sometimes say to her "you have to speak French, you know full well I'm French; if you

49 Original: 'la timidité réside dans la relation entre la situation ou la personne intimidante ... et la personne intimidée'.

50 Original: 'ça a été un gros souci pour moi. À un moment, mes enfants ne parlaient plus français, et vraiment, j'ai flippé là. J'étais dégoûtée. C'était important, par exemple, pour ma mère qui ne parlait pas anglais. Je les ai donc envoyés à l'école française.'

51 Original: 'une langue, c'est toute une tournure d'esprit, alors, si on ne la parle pas, je pense que cette tournure d'esprit elle diminue'. 
don't speak to me in French, it means you're ignoring me a bit, it means you're forgetting my origins ${ }^{\prime 52}$. Rather than a utopian third space, therefore, Marie's experience of her children's translanguaging is disruptive, destabilising her sense of self and requiring her to take action to redress the situation.

On an individuated level, then, Marie is experiencing what Ingram and Abrahams conceptualise as a 'Destabilized habitus' (2016, p. 148; original italics). This is a 'conjunctive' typology, whereby the 'person tries to incorporate the structuring forces of each field [pre- and postmigration] into their habitus but cannot achieve successful assimilation. Instead they oscillate between two dispositions and internalise conflict and division' (Ingram and Abrahams 2016, p. 148). Although Marie may previously have been able to incorporate both fields on a subjective level, the awakening to her children's 'identity slippage' (Mulholland and Ryan 2011, p. 5) and their emerging 'Abandoned habitus-divided from [the] originary field' (Ingram and Abrahams 2016, p. 148), expressed through their loss of the French language, triggers a disconcerting hysteresis effect. In an attempt to re-stabilise her own habitus and exercise some control over the structuring effects of the postmigration linguistic field forces, Marie takes the agentive step to impose a 'Re-confirmed habitus-divided from [the] new field' (Ingram and Abrahams 2016, p. 148) on her progeny by immersing them in the (diasporic) French educational field. To conceptualise Marie's experience of postmigration translanguaging as the embodiment of transnational embeddedness and a vocalisation of the diasporic third space would, therefore, negate the complex identity struggles at play.

Like Marie, Chantal also describes opting for the French education system as a mechanism for ensuring her children's command of French and stabilising the habitus. This, by extension, minimises the breach perceived to be growing between her children and older family members, as well as between her children's linguistic habitus and her own. Chantal considers it:

important that the children acquire our language, our mother tongue ... We thought it was important that they go to a French school ... We wanted to give them the language and the French culture too. Then it's up to them ... When they go back to France, that's what they miss actually. When we see them with their cousins, the big difference is that the others have never left their country, they only speak one language, and they look at them like aliens, because they can speak English ${ }^{53}$.

For Chantal and her husband, their children's acquisition of the mother tongue to a 'native' level of fluency is key to their identity as French citizens, albeit born and raised in London. Yet, paradoxically, it is the symbolic capital of the children's linguistic habitus, their fluency in both French and English, that prevents them from being fully integrated in either cultural context: in London, their membership of the French Lycée and the South Kensington French community gives them an exclusive identity, set apart from the arguably more integrated London-French who attend local English schools, and in France, they are estranged from their Franco-French cousins, who perceive them as 'aliens', purely because they do not conform to the dominant monolingual norm. In this sense, rather than bringing symbolic dividends, positioning them in a utopian translingual third space, their effortless translanguaging serves as a liability, compromising embedding and belonging in both diasporic and 'originary' spaces. It nonetheless strengthens in-group belonging and embedding within the sub-community of the South Kensington educational field ('that's what they miss').

52 Original: 'Il faut insister, sinon ça disparaît ... je lui dis parfois 'il faut que tu parles français, tu sais bien que je suis française moi; si tu ne me parles pas français, ça veut dire que tu m'ignores un peu, ça veut dire que tu oublies mes origines'.

53 Original: 'important que les enfants possèdent notre langue, notre langue maternelle ... On trouvait que c'était important qu'ils aillent à l'école française ... On avait voulu leur donner la langue, et puis la culture française aussi. Après, c'est eux qui choisissent ... Quand ils rentrent en France, c'est ce qui leur manque en fait. Quand on les voit avec leurs cousins et cousines, c'est ça la grosse différence: c'est que les autres n'ont jamais quitté leur pays, ils ne parlent qu'une langue, ils les regardent comme des aliennes, comme ils arrivent à parler anglais.' 
In the following extracts, we discover how the apparent 'easiness' in the English language expressed by Brice and Robert above, conceals more complex and adversative undercurrents. The alienation Chantal witnessed in relation to her children's translanguaging in the premigration field goes yet further in Brice's case, where his transmuting accent causes a profound sense of othering. In his own words, when returning to Carcasonne, his 'hometown', he feels 'almost like a foreigner' 54 . His experience consequently inverts the traditional model where migrants undergo 'internalised struggles that can occur when encountering unfamiliar fields' postmigration, and where 'decisions on whether to adapt to or resist our new host societies' are confronted (Thatcher and Halvorsrud 2016, p. 88). Having steadily - though perhaps not as purposively as Thatcher and Halvorsrud contend-adapted to the host society, Brice's transformed linguistic habitus renders him a 'fish out of water' in the premigration social space, a stranger to others, but also to himself, abruptly (made) aware of his own 'drift of character, corrosion of the self' (Elliott 2008, p. 140):

I'm not really an Englishman, even if I've been here a long time and people often tell me they can't hear my French accent ... I'm not completely French either because I don't know all the points of reference from the last 15 years, and recently even, I was in France ... and someone asked my cousin: 'who's that Englishman?' because he found I had a slightly strange accent when I spoke French $^{55}$.

Despite Brice's externally perceived convincing accent in English in the postmigration space, his primary (linguistic) habitus continues to deny him access to full 'Englishness' internally (Marx 2002). Conversely, despite his internal sense of a foundational French linguistic habitus, the protraction of his migration and subsequent loss of French cultural referents (Blommaert et al. 2005), together with the external symbolic affordances of his transformed accent, place him on the margins of 'Frenchness' in the premigration field. Since 'any kind of capital ... is perceived through categories of perception which are the product of the incorporation of divisions' (Bourdieu 1994, p. 117) ${ }^{56}$, Brice's transnational linguistic capital functions as an embodied marker of difference. His translanguaging thus extends beyond code-switching to the socialisation level of (popular) culture and the corporeal level of accent, which, in the words of octogenarian Suzanne, is a transnational 'accent somewhat in-between-both' lands, whose adrift positioning causes her to 'feel somewhat seasick ${ }^{\prime 57}$. This sense of queasiness and the internalised tension described by Brice suggests the translingual space is not solely the positive third space initially intimated. It is simultaneously associated with division, displacement and unbelonging, triggering an unease indicative of the hysteresis effect: Brice's linguistic habitus is at odds with the external structures of a space that was previously 'home'. Such disembedding and internal disjuncture confirms that Brice's selfhood, when confronted with the premigration field, corresponds to a cleft habitus, experienced as an 'abandoned habitus', increasingly divided from the originary social space and representative of neither a conjunctive form of hybridity nor a transcendental third space.

Robert experiences similar linguistic habitus hysteresis. In his case, however, the 'structural discrepancy' is rooted in lexical lacunae (like Brigitte), rather than accent, and

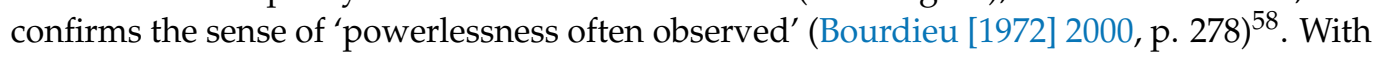
regular translanguaging causing considerable losses in linguistic capital, Robert commands

54 Original: 'presque comme un étranger'.

55 Original: 'je ne suis pas vraiment un Anglais, même si ça fait longtemps que je suis ici, et souvent on me dit qu'on entend pas mon accent français ... Je ne suis pas complètement français non plus parce que je ne connais pas toutes les références des derniers 15 ans, et même récemment j'étais en France ... et quelqu'un a demandé à mon cousin: "C'est qui cet Anglais?" parce qu'il trouvait que j'avais un accent un peu bizarre quand je parlais français.'

56 Original: 'toute espèce de capital ... est perçue à travers des catégories de perception qui sont le produit de l'incorporation des divisions'.

57 Original: 'accent un peu entre-les-deux' ... 'donne un peu le mal de mer'.

58 Original: 'décalage structural' ... 'l'impuissance souvent observée'. 
neither English nor French with the ease and intuition typical of the primary linguistic habitus. He describes this unsettling situation in the following terms:

[English] remains my second language, even if I speak it well. Maybe, deep down, $I^{\prime} m$ not a pure linguist ... I'm now at the point where my French sometimes gets difficult and my English isn't that great either, so I sometimes feel a bit caught between the two. It's strange. It's a bit of a no man's land ... I feel a bit stuck between the two ${ }^{59}$.

This poignant admission from one who has made language acquisition his livelihood conveys the linguistic, and by extension identity, dislocation experienced by Robert as a result of his long-term transnational experience. Caught in between two language spaces, he is ensnared in a symbolic 'no-man's land', devoid of solid culturo-linguistic anchorage and seemingly unable to escape his perpetual state of otherness. It is relevant to add here that Robert's words echo, with uncanny likeness, those used by Meredith Doran in relation to Paris's diasporic ethnic minorities: 'the same ideological hegemony which has undergirded the construction of a monolithic French identity has also traditionally denied the possibility of "non-standard" identities within its borders ... placing minority youths in a kind of "no man's land" of identity, caught at a crossroads between "immigrant" and "French"' (Doran 2004, p. 95). Thus, although his migratory act has freed Robert from the universalist devastation of the premigration space, it has simultaneously-and paradoxically-relegated him to a multilingual hinterland. Having subverted his predestined monolingual habitus, Robert finds himself stranded between two languages and two identities. He has undermined the pre-reflexive linguistic practices inherent in his originary habitus, but is unable to develop equally instinctive language production skills in the diasporic language space: 'it's strange, sometimes I mix English and French, and sometimes I speak in English without realising it ... I have to think in both languages $\ldots$ and sometimes to anticipate ... so as to not look for my words -it's strange ${ }^{\prime 60}$. This resonates further with testimony from Miranda, who emphasises the intellectual investment required in formerly straightforward linguistic interactions:

when I go home ... first I have to find my dialect again ... the accent, the dialect, not let any English words out in an English accent, get the structures right ... It's tiring sometimes. I have to search, search and search, and it's hard ${ }^{61}$.

Combining the problematic accent and lexical lacunae experiences of Brice and Robert with additional syntactic struggles, Miranda's account sheds light on the multiplicity of linguistic hurdles posed by the transnational languaging space (Szyszka 2020). At this point in their narratives, rather than perceiving the acquisition of English linguistic capital as an asset-a premigration symbolic pull factor cited by many research participants-both Robert and Miranda experience their transforming linguistic habitus as a deficit, a dispositional loss leaving them at a loss for words and lost in a disorientating transnational space. We hence rediscover Abdelmalek Sayad's conception of migration as a 'double absence' (Sayad 1999), but a rhetorical absence that gives rise to an absence of emplacement, articulated through the notions of strangeness, difficulty and desertion. Marooned between French and English linguistic spaces, Robert has become a stranger with a strange relationship to his tongue, a foreign body in both pre- and postmigration spaces. He feels trapped in a rhetorical wasteland, side-lined through a linguistic hysteresis effect that has left him bereft of the intuitive languaging dispositions he once took for granted. The otherness produced through Robert's unwieldy translanguaging contradicts his allusion to being 'at

59 Original: '[l'anglais] reste encore ma deuxième langue, même si je la pratique bien; peut-être qu'au fond de moi, je ne suis pas un pur linguiste ... Je suis maintenant au point où mon français devient parfois difficile, et mon anglais il n'est pas au top non plus. Donc je me sens un peu parfois pris entre les deux en fait. C'est étrange. C'est un peu un no man's land... Je me sens un peu coincé entre les deux'.

60 Original: 'c'est bizarre, des fois je fais un mélange d'anglais et français, ou parfois je parle en anglais sans m'en rendre compte.... Je suis obligé de réfléchir dans les deux langues ... et parfois d'anticiper ... pour ne pas chercher mes mots-c'est étrange'.

61 Original: 'quand je rentre ... déjà il faut que je retrouve mon dialecte ... l'accent, le dialecte, ne pas sortir les mots anglais avec un accent anglais, sortir les bonnes structures ... C'est fatigant des fois. Je cherche, je cherche, je cherche, et c'est dur'. 
ease' in the English language and further problematises the comfortable double-personality he reports when speaking French and/or English. His translanguaging, like Mrianda's and Brice's, now conjures inner struggle and dichotomy, and confirms an emerging cleft habitus: 'torn ... in the form of tensions and contradictions' (Bourdieu 1997, p. 79) ${ }^{62}$.

Based on the linguistic repertoires, subjectivities and spatialities presented in this subsection, the limits of translanguaging as a positive force have been tested and proven to be more steadfast than initially posited. Participants' experiences have illustrated how negotiating the language spaces of pre- and postmigration fields can be conducive to a disorientating hysteresis effect, and ultimately result in a cleft habitus. They are 'neither the sum of the new and the old, nor half of what they were and half or what they are' (Block 2006, p. 28), but the conflicted embodiment (Brah 1996) of ambivalence, that is, 'the uncertainty of feeling a part and apart' (Block 2006, p. 26). This consequently challenges the transnational third space ideal and corroborates the internalised and externalised symbolic complexities of everyday London-French translanguaging practice.

\section{Conclusions}

This article set out to explore the multifarious symbolic capital losses and gains incurred when migrating from France to London. Whether in terms of embodied accent, embedded translanguaging practices or wider sociosemiotic affordances, the complexity of transposing one's primary linguistic habitus to the postmigration field and subsequently re-adapting the transformed linguistic habitus to the premigration field has been brought to bear. Fundamentally, by analysing the narratives of a diverse sample of London-French residents, the intrinsically dualistic nature of the diasporic experience has surfaced. In spite of their transnational positioning and instinctive translanguaging, the migrants found themselves confronted with stubborn binaries and firmly situated spatialities. As such, according to the pre- or postmigration translocal context, their accents were experienced at once as attractive and repulsive, liberating and constraining. Similarly, their evolving vernacular and pre-reflexive translanguaging served both to embed them in the diasporic space by strengthening in-group belonging, while at the same disembedding them from the people and places of the originary habitat, erecting an invisible symbolic boundary between them and loved-ones left behind. For some, this converted symbolic capital and (mis)placed impression of distinctive exclusivity engendered a perceived otherness characteristic of an uneasy hysteresis effect, which brought into question the idealistic notion of a constructivist diasporic 'trans' third space.

Moreover, participants' backgrounds and premigration trajectories were found to be of significance. They allowed some to generate greater symbolic capital postmigration and others to experience a loss, depending on the point of departure. Despite a shared positive anonymising and self-reinventing effect, mobility to the new field of symbolic and linguistic structures transpired to be differentiated. Indeed, for some, this differentiation was experienced in reverse, their linguistic habitus transformation leaving them out of place in the originary linguistic and social space. Therefore, while translanguaging was seen to have the potential for creativity, in-group bonding and community cohesion, to ignore its simultaneously disorientating and divisive affordances would be an oversimplification. This article has shown that mobility is messy, experiences are individuated, but common (trans)languaging practices are nevertheless identifiable.

Consequently, although migrant testimonies bore witness to the rise of an uncomfortable cleft habitus, which threatened to undermine the notion of a utopian translanguaging third space, importantly, this hysteresis effect was triggered when attempting to conform to standard monolingual speech. When the migrants were communicating amongst themselves, enjoying the effortlessness of their new, nonstandard, translocal franglais vernacular, their fluid linguistic repertoires and increasingly translingual habitus were associated with comfortableness, ease and in-group belonging. Perhaps, therefore, translanguaging can

62 Original: 'dechirés ... sous la forme de tensions et de contradictions'. 
be apprehended as a generative and fertile transcendental third space, but only among those who share a common sense of diasporic belonging and selfhood: a common-unity of practice apart, rather than a community of practice within.

Funding: This research received no external funding.

Institutional Review Board Statement: This study was conducted according to the guidelines of the Declaration of Helsinki, and approved by the Ethics Committee of the University of Westminster.

Informed Consent Statement: Informed consent was obtained from all subjects involved in this study.

Data Availability Statement: The data presented in this study are not publicly available due to restrictions in data collection policy and to protect participant anonymity.

Conflicts of Interest: The author declares no conflict of interest.

\section{References}

Abrahamsson, Niclas, and Kenneth Hyltenstam. 2009. Age of Onset and Nativelikeness in a Second Language: Listener Perception Versus Linguistic Scrutiny. Language Learning 59: 249-306. [CrossRef]

Akomolafe, Olusoji. 2021. African-born scholars and accent discrimination: the last acceptable form of prejudice. In African Scholars and Intellectuals in North American Academies: Reflections on Exile and Migration. Edited by Sabella Ogbobode Abidde. Oxford and New York: Routledge.

Appadurai, Arjun. 1990. Disjuncture and Difference in the Global Cultural Economy. Theory, Culture and Society 7: 295-310. [CrossRef] Auer, Peter, ed. 1984. Bilingual Conversation. Amsterdam: Benjamins.

Baratta, Alex. 2018. Accent and Teacher Identity in Britain: Linguistic Favouritism and Imposed Identities. London: Bloomsbury.

Barthes, Roland. 1957. Mythologies. Paris: Éditions du Seuil.

Beswick, Jaine. 2020. Identity, Language and Belonging on Jersey. London: Palgrave Macmillan. [CrossRef]

Beswick, Jaine, and Alicia Pozo-Gutiérrez. 2010. Migrant Identities, Sociolinguistic and Sociocultural Practices: Portuguese and Spanish Migrations to the South Coast of England. Portuguese Studies 1: 41-59. Available online: www.jstor.org/stable/41105330 (accessed on 6 March 2021).

Bhabha, Homi. 1994. The Location of Culture. New York: Routledge.

Blackledge, Adrian, and Angela Creese. 2010. Multilingualism. London: Continuum Press.

Block, David. 2006. Multilingual Identities in a Global City: London Stories. Basingstoke and New York: Palgrave Macmillan.

Blom, Jan-Petter, and John J. Gumperz. 1972. Social Meaning in Linguistic Structures: Code Switching in Northern Norway. In Directions in Sociolinguistics: The Ethnography of Communication. Edited by John J. Gumperz and Dell Hymes. New York: Holt, Rinehart and Winston, pp. 407-34.

Blommaert, Jan. 2010. The Sociolinguistics of Globalisation. New York: Cambridge University Press.

Blommaert, Jan, James Collins, and Stef Slembrouck. 2005. Spaces of multilingualism. Language and Communication 25: 197-216. [CrossRef]

Bourdieu, Pierre. 2002. Le Bal des célibataires: Crise de la société paysanne en Béarn. Paris: Éditions du Seuil. First published 1962.

Bourdieu, Pierre. 2000. Esquisse d'une théorie de la pratique. Paris: Éditions du Seuil. First published 1972.

Bourdieu, Pierre. 2001. Langage et pouvoir symbolique. Paris: Éditions du Seuil. First published 1982.

Bourdieu, Pierre. 1979. Les trois états du capital culturel. In Actes de la Recherche en Sciences Sociales. November. vol. 30, pp. 3-6. Available online: http://www.persee.fr/web/revues/home/prescript/article/arss_0335-5322_1979_num_30_1_2654 (accessed on 18 December 2020).

Bourdieu, Pierre. 1984. Homo Academicus. Paris: Éditions de Minuit.

Bourdieu, Pierre. 1989. La Noblesse de l'Etat. Grandes écoles et esprit de corps. Paris: Éditions de Minuit.

Bourdieu, Pierre. 1994. Raisons pratiques: sur la théorie de l'action. Paris: Éditions du Seuil.

Bourdieu, Pierre. 1997. Méditations pascaliennes. Paris: Éditions du Seuil.

Bourdieu, Pierre. 2002. Le bal des célibataires: Crise de la société paysanne en Béarn. Paris: Éditions du Seuil.

Bourdieu, Pierre. 2004. Esquisse pour une auto-analyse. Paris: Raisons d'agir.

Bourdieu, Pierre. 2005. Habitus. In Habitus: A Sense of Place, 2nd ed. Edited by Jean Hillier and Emma Rooksby. Aldershot: Ashgate, pp. 42-49.

Bourdieu, Pierre, and J.-C. Passeron. 1964. Les Héritiers. Les étudiants et la culture. Paris: Minuit.

Bourdieu, Pierre, and Jean-Claude Passeron. 1970. La Reproduction. Eléments pour une théorie du système d'enseignement. Paris: Minuit.

Bourdieu, Pierre, and Loï J. D. Wacquant. 1992. Réponses: Pour une anthropologie réflexive. Paris: Éditions du Seuil.

Brah, Avtar. 1996. Cartographies of Diaspora: Contesting Identities. London: Routledge.

Brahic, Bénédicte, and Maxime Lallement. 2018. From 'Expats' to 'Migrants': strategies of resilience among French movers in post-Brexit Manchester. Migration and Development 9: 8-24. [CrossRef] 
Braun, Michael, and Camelia Arsene. 2009. The demographics of movers and stayers in the European Union. In Pioneers of European Integration. Edited by Ettore Recchi and Adrian Favell. Cheltenham: Edward Elgar.

Burke, Ciaran, Jenny Thatcher, Nicola Ingram, and Jessie Abrahams. 2016. Introduction: the development of Bourdieu's intellectual heritage in UK sociology. In Bourdieu: The Next Generation. The Development of Bourdieu's Intellectual Heritage in Contemporary UK Sociology. Edited by Jenny Thatcher, Nicola Ingram, Ciaran Burke and Jessie Abrahams. London and New York: Routledge, pp. $1-7$.

Cacciatore, Francesco, and Guilia Pepe. 2019. Performing new identities: the community language of post-crisis Italian migrants in London. National Identities 21: 507-26. [CrossRef]

Cordier, Vladimir. 2005. Enfin un Boulot! Ou le parcours d'un jeune chômeur français à Londres. London: eVault First Publishiing.

Cox, Andrew. 2005. What are communities of practice? Journal of Information Science 31: 527-40. [CrossRef]

De Fina, Anna. 2006. Group identity, narrative and self-representations. In Discourse and Identity. Edited by Anna De Fina, Deborah Schiffrin and Michael Bamberg. Cambridge: Cambridge University Press, vol. 23, pp. 351-75.

De Fina, Anna, and Sabina Perrino. 2013. Transnational Identities. Applied Linguistics 34: 509-15. [CrossRef]

de Roquemaurel, Josselin. 2014. La Reine, la City et les grenouilles. Chroniques d'un Français de Londres. Paris: Éditions Albin Michel.

Debaene, Vincent. 2010. L'adieu au voyage: L'ethnologie française entre science et littérature. Paris: Gallimard.

Decoteau, Claire L. 2013. Hybrid Habitus: Toward a Post-colonial Theory of Practice. In Postcolonial Sociology (Political Power and Social Theory. Bingley: Emerald Group Publishing Limited, vol. 24, pp. 263-93. [CrossRef]

Derwing, Tracey. 2003. What Do ESL Students Say About Their Accents? The Canadian Modern Language Review 59: 547-67. [CrossRef]

Di Salvo, Margherita. 2017. Heritage language and identity in old and new Italian migrants in Toronto. In Italian communities Abroad: Multilingualism and migration. Edited by Margherita Di Salvo and Paola Moreno. Newcastle upon Tyne: Cambridge Scholars Publishing, pp. 75-96.

Doran, Meredith. 2004. Negotiating between bourge and racaille: Verlan as youth identity practice in suburban Paris. In Negotiation of Identities in Multilingualism Contexts. Edited by Aneta Pavlenko and Adrian Blackledge. Clevedon: Multilingual Matters, pp. 93-124.

Elliott, Anthony. 2008. Concepts of the Self. Cambridge: Polity.

Faucher, Charlotte, Olivier Rauch, Eric Simon, and Floriane Zuniga. 2015. Le Lycée Français Charles de Gaulle de Londres 1915-2015. London: Association des Anciens du Lycée Français de Londres.

Favell, Adrian. 2008. Eurostars and Eurocities: Free Movement and Mobility in an Integration Europe. Oxford: Blackwell.

Friedman, Sam. 2016. The limits of capital gains: using Bourdieu to understand social mobility into elite occupations. In Bourdieu: The Next Generation. The Development of Bourdieu's Intellectual Heritage in Contemporary UK Sociology. Edited by Jenny Thatcher, Nicola Ingram, Ciaran Burke and Jessie Abrahams. London and New York: Routledge, pp. 107-22.

García, Ofelia, and Ricardo Otheguy. 2014. Spanish and Hispanic bilingualism. In The Routledge Handbook of Hispanic Applied Linguistics. Edited by Manel Lacorte. New York: Routledge, pp. 639-58.

Giles, Howard, and Patricia Johnson. 1987. Ethnolinguistic identity theory: A social psychological approach to language maintenance. International Journal of the Sociology of Language 68: 69-99. [CrossRef]

Giles, Howard, Donald M. Taylor, and Richard Bourhis. 1973. Towards a theory of interpersonal accommodation through language: Some Canadian data. Language in Society 2: 177-92. [CrossRef]

Hall, Stuart. 1997. Representation: Cultural Representations and Signifying Practices. London: Sage \& The Open University.

Hardy, Cheryl. 2012. Hysteresis. In Pierre Bourdieu—Key Concepts. Edited by Michael Grenfell. Durham: Acumen.

Harrison, Michelle, and Aurélie Joubert, eds. 2019. French Language Policies and the Revitalisation of Regional Languages in the 21st Century. Basingstoke: Palgrave Macmillan.

Holmes, Janet. 2018. Sociolinguistics vs pragmatics: Where does the boundary lie? In Pragmatics and its Interfaces. Edited by Cornelia Ilie and Neal R. Norrick. Amsterdam: John Benjamins, pp. 11-32. [CrossRef]

Huc-Hepher, Saskia. 2015. Big Web data, small focus: An ethnosemiotic approach to culturally themed selective Web archiving. Big Data \& Society, 1-15. [CrossRef]

Huc-Hepher, Saskia. 2019. 'Sometimes there's racism towards the French here': xenophobic microaggressions in pre-2016 London as articulations of symbolic violence. National Identities 23: 15-39. [CrossRef]

Huc-Hepher, Saskia. 2021. in press. French London: A Blended Ethnography of a Migrant City. Manchester: Manchester University Press.

Huc-Hepher, Saskia. under review. Queering the Web Archive: A Xenofeminist Approach to Gender, Functionality, Language and Culture in the London French Special Collection. Humanities and Social Sciences Communications.

Ingram, Nicola, and Jessie Abrahams. 2016. Bourdieu: The Next Generation. The Development of Bourdieu's Intellectual Heritage in Contemporary UK Sociology. Edited by Jenny Thatcher, Nicola Ingram, Ciaran Burke and Jessie Abrahams. London and New York: Routledge, pp. 140-156.

Kelly, Debra. 2013. Mapping Free French London. In A History of the French in London: Liberty, Equality, Opportunity. Edited by Debra Kelly and Martyn Cornick. London: Institute of Historical Research, University of London, pp. 303-41.

Koven, Michèle. 2007. Selves in Two Languages: Bilinguals' Verbal Enactments of Identity in French and Portuguese. Amsterdam and Philadelphia: John Benjamins.

Koven, Michèle. 2013. Speaking French in Portugal: An analysis of contested models of emigrant personhood in narratives about return migration and language use. Journal of Sociolinguistics 17: 324-54. [CrossRef] 
Kress, Gunther. 2010. Multimodality: A Social Semiotic Approach to Contemporary Communication. London and New York: Routledge. Lehmann, Wolfgang. 2013. Habitus Transformation and Hidden Injuries: Successful Working-class University Students. Sociology of Education 87: 1-15. [CrossRef]

Levis, John M. 2016. Accent in second-language pronunciation research and teaching. Journal of Second Language Pronunciation 2: 153-59. [CrossRef]

Lewis, Gwyn, Bryn Jones, and Colin Baker. 2012. Translanguaging: Origins and development from school to street and beyond. Educational Research and Evaluation 18: 641-54. [CrossRef]

Li, Wei. 2011. Moment Analysis and translanguaging space. Journal of Pragmatics 43: 1222-35. [CrossRef]

Li, Wei. 2016. Multi-competence and the translanguaging instinct. In The Cambridge Handbook of Multi-Competence. Edited by Vivian Cook and Wei Li. Cambridge: Cambridge University Press, pp. 533-43.

Li, Wei. 2018. Translanguaging as a Practical Theory of Language. Applied Linguistics 39: 9-30. [CrossRef]

Li, Wei, and Hua Zhu. 2013. Translanguaging Identities and Ideologies: Creating Transnational Space Through Flexible Multilingual Practices Amongst Chinese University Students in the UK. Applied Linguistics 34: 516-35. [CrossRef]

Lippi-Green, Rosina. 2012. English with an Accent: Language, Ideology, and Discrimination in the United States, 2nd ed. London: Routledge. MacSwan, Jeff. 2017. A Multilingual Perspective on Translanguaging. American Educational Research Journal 54: 167-201. [CrossRef]

Marx, Nicole. 2002. Never Quite a 'Native Speaker': Accent and Identity in the L2—and the L1. The Canadian Modern Language Review 59: 264-81. [CrossRef]

McCrocklin, Shannon, and Stephanie Link. 2016. Accent, Identity, and a Fear of Loss? ESL Students' Perspectives. The Canadian Modern Language Review 72: 122-48. [CrossRef]

Ministère de l'Europe et des Affaires étrangères. 2019. Français résidant à l'étranger: Les chiffres 2019 du registre consulaire. Available online: https:/ / webapps.france-diplomatie.info/carte-registre/ (accessed on 17 December 2020).

Moyer, Alene. 2011. An Investigation of Experience in L2 Phonology: Does Quality Matter More than Quantity? The Canadian Modern Language Review 67: 191-216. [CrossRef]

Mulholland, Jon, and Louise Ryan. 2011. French Capital: A Study of French Highly-Skilled Migrants in London's Financial and Business Sectors_Preliminary Findings Report. Middlesex: ESRC/Middlesex University.

Mulholland, Jon, and Louise Ryan. 2014a. Doing the Business: Variegation, Opportunity and Intercultural Experience among Intra-EU Highly-Skilled Migrants. International Migration 52: 55-68. [CrossRef]

Mulholland, Jon, and Louise Ryan. 2014b. 'Londres Acceuil': Mediations of Identity and Place among the French Highly Skilled in London. In Migrant Professionals in the City: Local Encounters, Identities and Inequalities, 1st ed. Edited by Lars Meier. London and New York: Routledge, pp. 169-86.

Mulholland, Jon, and Louise Ryan. 2016. London is a much more interesting place than Paris: Place comparison and moral geographies of highly skilled migrants. In Rethinking International Skilled Migration. Edited by Micheline van Riemsdijk and Qingfang Wang. London and New York: Routledge, pp. 135-53.

Nyobe, Sara, and Jean-Michel Plane. 2020. Hybrid HRM as a framework for handling cultural dominance issues at work. Revue de Gestion des Ressources Humaines 115: 5-18. [CrossRef]

Office for National Statistics. 2017. Living Abroad: migration between Britain and France. Available online: https://www. ons.gov.uk/peoplepopulationandcommunity/populationandmigration/internationalmigration/articles/livingabroad/ dynamicsofmigrationbetweenbritainandfrance\#what-are-french-citizens-living-in-the-uk-doing (accessed on 17 December 2020).

Otheguy, Ricardo, Ofelia García, and Wallis Reid. 2015. Clarifying translanguaging and deconstructing named languages: A perspective from linguistics. Applied Linguistics Review 6: 281-307. [CrossRef]

Pahl, Kate. 2019. Reflecting on reflections. In Bourdieu, Language-based Ethnographies and Reflexivity: Putting Theory into Practice. Edited by Michael Grenfell and Kate Pahl. New York: Routledge, pp. 133-47.

Phipps, Alison. 2020. Me, Not You: The Trouble with Mainstream Feminism. Manchester: Manchester University Press.

Pulley, Tifanie, and Arthur Whaley. 2020. Embodying a Hybrid Habitus: Identity Construction and Social Mobility among Workingclass Black Women. In Introduction to Africana Demography: Lessons from Founders E. Franklin Frazier, W.E.B. Du Bois and the Atlanta School of Sociology. Leiden: Brill, pp. 165-86. [CrossRef]

Reed-Danahay, Deborah. 2020a. Brexit, Liminality, and Ambiguities of Belonging: French Citizens in London. Ethnologia Europaea 50: 16-31. [CrossRef]

Reed-Danahay, Deborah. 2020b. Leave/Remain: Brexit, Emotions, and the Pacing of Mobility among the French in London. In Pacing Mobilities. Edited by Vered Amit and Noel B. Salazar. Oxford and New York: Berghahn Books, pp. 142-62.

Ryan, Louise, and Jon Mulholland. 2013. Trading Places: French Highly Skilled Migrants Negotiating Mobility and Emplacement In London. Journal of Ethnic and Migration Studies 40: 584-600. [CrossRef]

Ryan, Louise, and Jon Mulholland. 2014. French connections: the networking strategies of French highly skilled migrants in London. Global Networks 14: 148-66. [CrossRef]

Sayad, Abdelmalek. 1999. La Double Absence. Paris: Le Seuil.

Seloni, Lisya. 2019. Enacting Reflexivity in Second Language Writing Research: A Personal Account of Cultural Production of Authorial Self and Researcher Perception. In Bourdieu, Language-based Ethnographies and Reflexivity: Putting Theory into Practice. Edited by Michael Grenfell and Kate Pahl. New York: Routledge, pp. 107-29.

Senni, Hamid. 2007. De la Cité à la City. Paris: L'Archipel. 
Sheringham, Olivia. 2010. A Transnational Space? Transnational Practices, Place-Based Identity and the Making of 'Home' among Brazilians in Gort, Ireland. Portuguese Studies 26: 60-78. Available online: http:/ / www.jstor.org/stable/41105331 (accessed on 6 March 2021).

Sprio, Margherita. 2013. Migrant Memories: Cultural History, Cinema and the Italian Post-War Diaspora in Britain. Bern: Peter Lang.

Szyszka, Magdalena. 2020. Learners' attitudes to first, second and third languages pronunciation in structuring multilingual identity. Applied Linguistics Review. [CrossRef]

Thatcher, Jenny, and Kristoffer Halvorsrud. 2016. Migrating habitus: a comparative case study of Polish and South African migrants in the UK. In Bourdieu: The Next Generation. The Development of Bourdieu's Intellectual Heritage in Contemporary UK Sociology. Edited by Jenny Thatcher, Nicola Ingram, Ciaran Burke and Jessie Abrahams. London and New York: Routledge, pp. 88-106.

UNESCO. 2010. The gastronomic meal of the French. Youtube. Available online: https://youtu.be/6nKBBb72J4k (accessed on 25 January 2021).

Vertovec, Steven. 2007. Super-diversity and its implications. Ethnic and Racial Studies 30: 1024-54. [CrossRef]

Wallace, Derron O. 2016. Bourdieu and Black identities. In Bourdieu: The Next Generation. The Development of Bourdieu's Intellectual Heritage in Contemporary UK Sociology. Edited by Jenny Thatcher, Nicola Ingram, Ciaran Burke and Jessie Abrahams. London and New York: Routledge, pp. 37-54.

Wells, Naomi, Charles Forsdick, Jessica Bradley, Charles Burdett, Jennifer Burns, Marion Demossier, Margaret Hills de Zárate, Saskia Huc-Hepher, Shirley Jordan, Thea Pitman, and et al. 2019. Ethnography and Modern Languages. Modern Languages Open 1. [CrossRef]

Wenger, Etienne. 1998. Communities of Practice. Cambridge: Cambridge University Press.

Wenger, Etienne. 2004. Knowledge Management as a Doughnut. Ivey Business Journal. Available online: https://iveybusinessjournal. $\mathrm{com} /$ publication/knowledge-management-as-a-doughnut/ (accessed on 13 January 2021). 